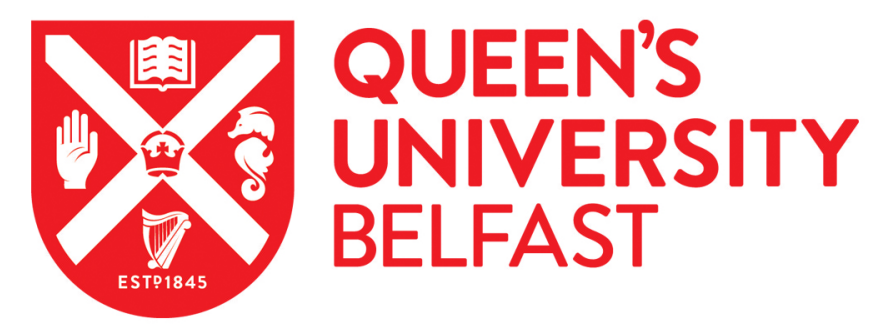

\title{
Cultural change and the climate record in final prehistoric and early medieval Ireland
}

Coyle McClung, L., \& Plunkett, G. (2020). Cultural change and the climate record in final prehistoric and early medieval Ireland. Proceedings of the Royal Irish Academy: Section C, Archaeology, Celtic Studies, History, Linguistics, Literature, 120C, 129-158. https://doi.org/10.3318/priac.2020.120.04

Published in:

Proceedings of the Royal Irish Academy: Section C, Archaeology, Celtic Studies, History, Linguistics, Literature

Document Version:

Peer reviewed version

Queen's University Belfast - Research Portal:

Link to publication record in Queen's University Belfast Research Portal

Publisher rights

(C) 2020 Royal Irish Academy.

This work is made available online in accordance with the publisher's policies. Please refer to any applicable terms of use of the publisher.

\section{General rights}

Copyright for the publications made accessible via the Queen's University Belfast Research Portal is retained by the author(s) and / or other copyright owners and it is a condition of accessing these publications that users recognise and abide by the legal requirements associated with these rights.

Take down policy

The Research Portal is Queen's institutional repository that provides access to Queen's research output. Every effort has been made to ensure that content in the Research Portal does not infringe any person's rights, or applicable UK laws. If you discover content in the Research Portal that you believe breaches copyright or violates any law, please contact openaccess@qub.ac.uk. 


\title{
CULTURAL CHANGE AND THE CLIMATE RECORD IN FINAL PREHISTORIC AND EARLY MEDIEVAL IRELAND
}

\author{
Lisa Coyle-McClung AND Gill PlunKetT* \\ Archaeology and Palaeoecology, School of Natural and Built Environment, Queen's \\ University Belfast, Northern Ireland.
}

\begin{abstract}
To what extent did climate change steer the trajectories of early societies? The final prehistoric (Developed to Late Iron Age) and early medieval periods in Ireland witnessed several major transformations in settlement, economy, material culture and ideology. Here, we review the palaeoenvironmental records to contextualise these transformations in terms of both climate oscillations and land-use history to evaluate whether climate change may have played a role in altering the socio-economic or political framework. We find little evidence that climate change coincided with major cultural alterations in the archaeological record, with pollen records providing important insights into ongoing human activity during times of reduced archaeological visibility. Although palaeoenvironmental records rarely provide sufficient chronological resolution with which to test the effects of abrupt environmental changes on populations, we note no lasting impacts following the proposed downturns that would implicate climate as a determinant of enduring cultural change during these periods.
\end{abstract}

\section{Introduction}

There is a frequent, if often implicit, tendency to assume that cultural transitions of past societies were environmentally-driven and that climatic deteriorations, through their detrimental effects on the environment and subsistence economy, were the main agents of cultural decline. ${ }^{1}$ This environmentally-deterministic theory is often considered over and above other more intrinsic factors such as socio-political or economic turmoil. Climate does assert an important influence on the success and productivity levels of farming economies, but the relationship between climate and culture is not straightforward. Various complex influences - including social structure, technology and resources - will determine whether a community is sufficiently resilient to adapt and flourish at times of climate change or collapse into crisis. ${ }^{2}$ Even when the occurrence of past climate changes can be substantiated,

* Author's email: G.Plunkett@qub.ac.uk

ORCID ID: https://orcid.org/0000-0003-1014-3454

doi: https://doi.org/10.3318:/PRIAC.2020.120.04

${ }^{1}$ M.G.L. Baillie and M.A.R. Munro, 'Irish tree rings, Santorini and volcanic dust veils', Nature 332 (1988), 344-6; M.G.L. Baillie, 'Great oaks from little acorns...: precision and accuracy in Irish dendrochronology', in F.M. Chambers (ed.), Climate change and human impact on the landscape (London 1993), 33-41; Ulf Büntgen et al., '2500 years of European climate variability and human susceptibility', Science 331 (2011), 578-82.

${ }^{2}$ P.B. deMenocal, 'Cultural responses to climate change during the late Holocene', Science 292 (2001), 667-3; K.W. Butzer, 'Collapse, environment, and society', Proceedings of the National 
establishing a temporal correlation - much less a causal link — between climate and cultural change is fraught with difficulties, given the chronological uncertainties that frequently beset both the archaeological and palaeoclimate records.

Typically, environmentally deterministic models of past cultural change have focused on the impact climate change exerted on the subsistence base. ${ }^{3}$ Such a premise lends itself to testing through an examination of the palynological record. Landscape manipulation has long been associated with the subsistence economies of past populations and the pollen record can highlight key transitions in agricultural management. Simply put, the pollen record provides insight into the nature and intensity of farming in the past, though interpretation of the data can be complex. Ideally, pollen and palaeoclimate reconstructions from the same sedimentary sequence enable the relative timing of past climate and land-use changes to be identified unequivocally. ${ }^{4}$ Few such studies have yet been undertaken, however, perhaps partly due to a lack of interdisciplinary engagement.

The end of the prehistoric era (the Developed to Late Iron Age) and the dawn of the historic (early medieval) period in Ireland feature several culturally distinct developments within the archaeological record, including 'periods of much building, 5 , changes in settlement types and patterns, and changes in economic practices. Perhaps not surprisingly, these changes have been attributed by some to climate fluctuations that at times benefitted, and at times undermined, social development (Table 1). ${ }^{6}$ This paper explores the likelihood of environmentally-driven cultural change in Ireland during the Developed to Late Iron Age and early medieval period by (i) reviewing archaeological evidence for cultural developments during these times that have been attributed to climate variability; (ii) evaluating palaeoclimate records from Ireland to identify potential climate events and transitions; and

Academy of Sciences 109 (2012), 3632-9; Jago Cooper, 'Weathering climate change. The value of social memory and ecological knowledge', Archaeological Dialogues 19 (2012), 46-51; T.J. Wilkinson, 'Weather and climate proxy records', Archaeological Dialogues 19 (2012), 57-62.

${ }^{3}$ Robert van de Noort, 'Conceptualising climate change archaeology', Antiquity 85 (2011), 1039-48; Toby Pillatt, 'From climate and society to weather and landscape', Archaeological Dialogues 19 (2012), 29-42.

${ }^{4}$ Gill Plunkett, 'Tephra-linked peat humification records from Irish ombrotrophic bogs question nature of solar forcing at $850 \mathrm{cal}$. yr BC', Journal of Quaternary Science 21 (2006), 9-16; Gill Plunkett, 'Socio-political dynamics in later prehistoric Ireland: Insights from the pollen record', in T.L. Thurston and R.B. Salisbury (eds), Reimagining regional analyses: The archaeology of spatial and social dynamics (Cambridge, 2009), 42-66.

${ }^{5}$ Richard Warner, 'Tree-rings, catastrophes and culture in Early Ireland: Some comments', Emania 11 (1993), 13-9: 13.

${ }^{6}$ Iron Age population collapse: D.A. Weir, 'An environmental history of the Navan area, Co. Armagh', unpublished PhD thesis, Queen's University Belfast, 1993; Impacts of dust veil events at 207 BC, 44-42 BC and AD 536-540: M.G.L. Baillie, 'Dark ages and dendrochronology', Emania 11 (1993), 5-12; M.G.L. Baillie, 'Patrick, comets and Christianity', Emania 13 (1995), 69-78; Tenth century decline: D.M. Brown and M.G.L. Baillie, 'Confirming the existence of gaps and depletions in the Irish oak tree-ring chronology', Dendrochronologia 30 (2012), 85-91. 
(iii) examining pollen records to identify if cultural or palaeoclimate changes coincided with variations in subsistence economy.

\section{Cultural developments in final prehistoric and early medieval Ireland}

The to-ing and fro-ing of the Irish Iron Age

The Irish Iron Age (c. 700 BC-AD 400) has long been known for the emergence of largescale construction projects and the manufacture of elaborate metalwork and apparent ritualised offerings, ${ }^{7}$ all of which materialised during the last three centuries BC in the period now known as the Developed Iron Age. The scale of collaboration needed for the monumental constructions of this period has been taken to signify the emergence of a new ruling-class keen to establish their territorial boundaries. ${ }^{8}$ Navan Fort (Emain Macha), Co. Armagh, Knockaulin (Dún Ailinne), Co. Kildare, Rathcroghan (Cruachain), Co. Roscommon, and Tara (Teamhair), Co. Meath, have frequently been referred to in the literature as 'royal' sites. These localities are embedded in Irish mythology describing warrior champions such as Cú Chulainn; ${ }^{9}$ and are believed to have been ceremonial centres and places of assembly. ${ }^{10}$ Dendrochronological dating of an oak timber post from the ' $40 \mathrm{~m}$ structure' at Navan Fort placed its construction at $95 \mathrm{BC},{ }^{11}$ and excavations at Knockaulin suggest it, too, is broadly contemporary, though perhaps a little later. ${ }^{12}$ Additional building developments included extensive manmade linear earthworks, such as the impressive Black Pig's Dyke, thought to be an ancient boundary in southern Ulster. Oak timbers from a section of the Dyke, known as the Dorsey, Co. Armagh, were dendrochronologically dated to $140 \mathrm{BC}$ and $95 \mathrm{BC},{ }^{13}$ the younger date concurrent with that derived from the Navan Fort central post. A date of 148 $\mathrm{BC}$ was recorded from Corlea, Co. Longford, ${ }^{14}$ arguably the most impressive of Irish wetland

${ }^{7}$ Barry Raftery, Pagan Celtic Ireland: The enigma of the Irish Iron Age (London, 1994), 64 97, 147-199.

${ }^{8}$ Raftery, Pagan Celtic Ireland, 65; Ian Armit, 'Social landscapes and hidden identities in the Irish Iron Age', in Colin Hasselgrove and Tom Moore (eds), The later Iron Age in Britain and beyond (Oxford, 2007), 130-9.

${ }^{9}$ Ann Hamlin, 'Emain Macha: Navan Fort', Seanchas Ardmhacha: Journal of the Armagh Diocesan Historical Society 11 (1985), 295-300.

${ }^{10}$ S.A Johnston, 'Revisiting the Irish royal sites', Emania 20 (2006), 53-9; S.A. Johnston, P.J. Crabtree and D.V. Campana, 'Performance, place and power at Dún Ailinne, a ceremonial site of the Irish Iron Age', World Archaeology 46 (2014), 206-23; Patrick Gleeson, 'Assembly and élite culture in Iron Age and late Antique Europe: a case-study of Óenach Clochair, Co. Limerick', Journal of Irish Archaeology 23 (2014), 171-87: 171-2.

${ }^{11}$ M.G.L. Baillie, 'The dating of the timbers from Navan Fort and the Dorsey, Co. Armagh', Emania 4 (1988), 37-40.

${ }^{12}$ S.A. Johnston, 'Chronology', in S.A. Johnston and Bernard Wailes, 'Dún Ailinne: Excavations at an Irish royal site 1968-1975' (Dublin, 2007), 182.

${ }^{13}$ Baillie, 'The dating of the timbers from Navan Fort and the Dorsey'.

${ }^{14}$ Raftery, Pagan Celtic Ireland, 99. 
trackway (togher) constructions in the prehistoric period. Warner has proposed that such large-scale endeavours are symptomatic of a society under stress and Baillie has pointed to a growth downturn in Irish oaks at 207 BC that may bear testimony to an environmental trigger for such stress. ${ }^{15}$ In contrast, Becker has surmised that the Developed Iron Age arose amid a period of climatic improvement. ${ }^{16}$

The emergence of a new material culture in this period, comprising La Tène-style metalwork, has been associated with a warrior elite and horsemanship. ${ }^{17}$ Most of the Irish La Tène artefacts have been recovered from wetland environments suggesting they may have been ritualistic, votive offerings. ${ }^{18}$ There is also evidence for more gruesome ritual offerings. While bog bodies are not unique to Ireland and cover many cultural periods, those dated to the Iron Age display evidence for deliberate mutilation prior to death, intimating ceremonial killings or even sacrifices. It has been speculated that votive offerings in wetland sites, such as La Tène metalwork and bog bodies, were deliberately positioned to demarcate ancient political territories. ${ }^{19}$ In the $2015 \mathrm{BBC}$ production 4,000-year-old cold case: The body in the $b o g$, it was posited that such ritualised killings were prompted by climate deterioration.

The general scarcity of evidence for non-elite settlement throughout the period led Raftery to coin the phrase 'the invisible people' for the Iron Age population of Ireland. ${ }^{20}$ During the Late Iron Age (c. AD 1-400), the paucity of evidence is particularly acute. The available evidence suggests that large-scale structures ceased to be built although there are some indications that smaller-scale elite complexes were in use at the 'royal' sites of Navan Fort, Rathcroghan and Tara, and elsewhere at sites such as Raffin Fort. ${ }^{21}$ A recent study revealed an unambiguous hiatus in trackway building across Irish wetland sites dated between $c$. AD 25 and 400. ${ }^{22}$ A similar gap in construction was noted during the creation of the Belfast Oak Chronology with, until recently, no Irish archaeological oak timbers found

${ }^{15}$ Warner, 'Tree-rings, catastrophes and culture in early Ireland', 13-9; Baillie, 'Great oaks from little acorns'.

${ }^{16}$ Katharina Becker, 'Relics of old decency', in Gabriel Cooney et al. (eds), Archaeological studies in later prehistory: Festschrift for Barry Raftery (Dublin 2009), 353-61: 358.

${ }^{17}$ Raftery, Pagan Celtic Ireland, 141.

${ }^{18}$ Raftery, Pagan Celtic Ireland, 183; E.P. Kelly, 'Secrets of the bog bodies: The enigma of the Iron Age explained', Archaeology Ireland 20, no. 1 (2006), 26-30.

${ }^{19}$ Kelly, 'Secrets of the bog bodies'.

${ }^{20}$ Raftery, Pagan Celtic Ireland, 112.

${ }^{21}$ S.A. Johnston, 'Revisiting the Irish royal sites', Emania 20 (2006), 53-9; Eoin Grogan, 'The rath of the Synods, Tara, Co. Meath: Excavations by Seán P. Ó Riordáin' (Dublin, 2008), 97; Conor Newman, 'Reflections on the making of a "royal site" in early Ireland', World Archaeology 30 (1998), 127-41.

${ }^{22}$ Gill Plunkett et al., 'Environmental indifference? A critique of environmentally deterministic theories of peatland archaeological site construction in Ireland', Quaternary Science Reviews 61 (2013), 17-31. 
that dated between $40 \mathrm{BC}-\mathrm{AD} 550 .^{23}$ This seeming decline of the Iron Age culture in Ireland has long puzzled archaeologists, and the apparent paucity of the archaeological record over the early centuries AD led to speculation that there was a major demographic crisis, ${ }^{24}$ potentially triggered by a global volcanic dust-veil at 44-42 BC. ${ }^{25}$ Although about 400 sites of varying type attributable to the Late Iron Age can now be identified thanks to recent development-led rescue archaeology, ${ }^{26}$ the current archaeological record remains poorlydefined, characterised by little more than about a dozen houses, an assortment of burial and ritual sites, and an increasing body of artefactual remains indicating interactions with the Romano-British world. ${ }^{27}$ The vast majority of sites comprise hearths, pits and post-holes dating to the early centuries $\mathrm{AD}$, whose distribution reveals that Late Iron Age activity was in fact widespread across the island ${ }^{28}$. Recognition of this activity has been hindered, in the absence of absolute dates, by its often ephemeral and nondescript nature. Research on Romano-British artefacts and seemingly intrusive burials (inhumations that stand in contrast to the long-held tradition of cremation) in Ireland highlights two periods for which links between Ireland and the Roman and post-Roman world are particularly evident, namely the first-second centuries AD and fourth-sixth centuries AD ${ }^{29}$ Strontium analysis of tooth enamel from seven crouched burials dating to between the second century BC and second century $\mathrm{AD}$ confirms that three of the individuals were unlikely of local origin, but included migrants possibly from Britain; of three crouched burials dating to between the fourth and seventh centuries, two were non-local, one perhaps hailing from as far south as the Mediterranean, while eleven out of twenty extended inhumations were of non-local origin. ${ }^{30}$

${ }^{23}$ M.G.L. Baillie, 'Marking in marker dates: Towards an archaeology with historical precision', World Archaeology 23 (1991), 233-43.

${ }^{24}$ D.A. Weir, 'Dark ages and the pollen record', Emania 11 (1993), 21-30.

${ }^{25}$ Baillie, 'Great oaks from little acorns'; Brown and Baillie, 'Confirming the existence of gaps and depletions'.

${ }^{26}$ Ger Dowling, 'Landscape and settlement in late Iron Age Ireland: Some emerging trends. Late Iron Age and “Roman” Ireland', Discovery Programme Reports 8 (2014), 151-74: 151.

${ }^{27}$ Katharina Becker, 'Redefining the Irish Iron Age', in Michael Potterton and Christiaan Corlett (eds), Life and death in Iron Age Ireland (Dublin, 2012), 1-14; Cóilín Ó Drisceoil and E. Devine, 'Invisible people or invisible archaeology? Carrickmines Great, Co. Dublin, and the problem of Irish Iron Age settlement', in Christiaan Corlett and Michael Potterton (eds), Life and death in Iron Age Ireland in the light of recent archaeological excavations (Dublin, 2012), 249-65.

${ }^{28}$ Dowling, 'Landscape and settlement in late Iron Age Ireland'.

${ }^{29}$ Philip Freeman, 'The archaeology of Roman material in Ireland', Proceedings of the Harvard Celtic Colloquium 15 (1995), 69-74; Jacqueline Cahill Wilson, 'Romans and Roman material in Ireland: A wider social perspective', Discovery Programme Reports 8 (2014), 11-58; Jacqueline Cahill Wilson, Christopher Standish and Elizabeth O'Brien, 'Investigating mobility and migration in the later Irish Iron Age', Discovery Programme Reports 8 (2014), 127-49.

${ }^{30}$ Jacqueline Cahill Wilson and C.D. Standish, 'Mobility and migration in Late Iron Age and early medieval Ireland', Journal of Archaeological Science: Reports 6 (2016), 230-41. 
Others have suggested increased population mobility, perhaps associated with a more fragmented, kin-based system of social structure and a pastoral-based economy, as an alternative explanation for the perceived 'invisibility' of Late Iron Age folk. ${ }^{31}$ Dowling argues that there is a greater incidence of enclosed sites from the third century AD, perhaps a sign of more permanent ties with place, and highlights the growing recognition of Iron Age activity beneath early medieval raths and crannogs, that may betray the origins of this later settlement tradition. ${ }^{32}$ Recently, there has also been appreciation that corn-drying kilns were in use during the Late Iron Age, notably between AD 200-400. ${ }^{33}$ These sites have been considered as an indication of an expansion of cereal production despite 'an increasingly damp climate' ${ }^{34}$ and were possibly inspired by Romano-British parching ovens. ${ }^{35}$ Monk and Power note that that the earliest and greatest concentration of kilns centres around counties Dublin and Meath, ${ }^{36}$ where a considerable number of Roman finds and intrusive burials have been discovered. ${ }^{37}$ At Baysrath, Co. Kilkenny, the recovery of a possible Romano-British iron spearhead from a first-second century AD enclosed settlement associated with a corndrying kiln suggests that an external stimulus for this new technology was not restricted to north Leinster. ${ }^{38}$ There are, therefore, signs of changes within the economic structure of the Late Iron Age that may have been fuelled, if not driven, by connections with the Roman world. It is possible that the same connections inspired the formation of new social identities and fostered increasing social stratification. ${ }^{39}$

\section{Boom and bust in the early medieval period}

Immense cultural and economic changes occur within the early medieval period (c. AD 400 1100), with the emergence of new settlement types, shifts in agricultural practices, trackway

${ }^{31}$ C.J. Lynn, 'Ireland in the Iron Age: A basket case?', Archaeology Ireland 17, no. 2 (2003), 20-23; Armit, 'Social landscapes and hidden identities'; Brian Dolan, 'Beyond elites: Reassessing Irish Iron Age society', Oxford Journal of Archaeology 33 (2014), 361-77.

${ }^{32}$ Dowling, 'Landscape and settlement'.

${ }^{33}$ Scott Timpany, Mick Monk and Orla Power, 'Agricultural boom and bust in medieval Ireland: Plant macrofossil evidence from kiln sites along the N9/N10 road scheme', in Sheelagh Conran, Ed Danaher and Michael Stanley (eds), Past times, changing fortunes, National Roads Authority Monograph Series No. 8 (Dublin, 2011), 73-84; Mick Monk and Orla Power, 'More than a grain of truth emerges from a rash of corn-drying kilns', Archaeology Ireland 26, no. 2 (2012), 38-41; Mick Monk and Orla Power, 'Casting light from the fires of corn-drying kilns on the Later Irish Iron Age', Archaeology Ireland 28, no. 3 (2014), 39-42.

${ }^{34}$ Monk and Power, 'Casting light from the fires of corn-drying kilns on the Later Irish Iron Age', 42.

\footnotetext{
${ }^{35}$ Monk and Power, 'More than a grain of truth emerges from a rash of corn-drying kilns', 39.

${ }^{36}$ Monk and Power, 'More than a grain of truth emerges from a rash of corn-drying kilns', 39.

${ }^{37}$ Cahill Wilson and Standish, 'Mobility and migration'.

${ }^{38}$ Dowling, 'Landscape and settlement'.

${ }^{39}$ Armit, 'Social landscapes and hidden identities', 137.
} 
and watermill construction phases, and the spread of the Church and literacy. While the first missionaries arrived in the fifth century $\mathrm{AD}$, few textual sources pre-dating the seventh century survive. Along with annals, an extensive corpus of law tracts dating to the seventh and eighth centuries provide detailed insights into socio-economic and political structures, although only later copies of these texts have survived. ${ }^{40}$ Notably, the texts paint a picture of a fragmented political structure characterised by around 150-200 túatha (singular: túath) or petty kingdoms, ${ }^{41}$ while cows underpinned the Irish economy and were status markers of the wealthy elites during the early centuries of the early medieval period. ${ }^{42}$

In tandem with the spread of the Church, and in stark contrast to the Late Iron Age, we observe relatively abundant evidence for secular settlement near the start of the early medieval period. During the sixth century, the rath, or ringfort, emerged as the predominant settlement type. ${ }^{43}$ Generally interpreted as farmsteads surrounded by an earthen bank and ditch (vallum), these settlements have been closely associated with pastoral farming and their construction appears to have peaked during the seventh century. ${ }^{44}$ Crannogs - artificial islands typically, though not exclusively, associated with elites - were constructed in shallow lakes. While some date to the later prehistoric period, ${ }^{45}$ the early medieval crannogs appear to cluster in the late sixth to early seventh centuries and after the mid-eighth century (according to the temporal distribution of dendrochronologically-dated sites). ${ }^{46}$ This expansion in activity is matched by a large increase in the number of trackways built across Irish wetlands in the period $c$. AD 550-750. ${ }^{47}$ The dendrochronological record highlights that, more generally, oak-based constructions were at their height between AD 540 and $650 .{ }^{48}$ Although Timpany and colleagues identify evidence for a slight decrease in corn-drying kiln numbers during the sixth century, on a national level, these features peak between the fifth and seventh centuries, evidently expanding beyond Leinster from this time. ${ }^{49}$ Baillie has postulated that

${ }^{40}$ Fergus Kelly, Early Irish farming, a study based on the law-texts of the seventh and eighth centuries AD: with minor revisions and corrections (Dundalk, 2000), 6-7.

${ }^{41}$ Newman, 'Reflections on the making of a "royal site" in Ireland', 127-41.

${ }^{42}$ Kelly, Early Irish farming, 27.

${ }^{43}$ Thomas Kerr and Finbar McCormick, 'Statistics, sunspots and settlement: Influences on sum of probability curves', Journal of Archaeological Science 41 (2014), 493-501.

${ }^{44}$ Thomas Kerr, G.T. Swindles and Gill Plunkett, 'Making hay while the sun shines? Socioeconomic change, cereal production and climatic deterioration in early medieval Ireland', Journal of Archaeological Science 36 (2009), 2868-74.

${ }^{45}$ Christina Fredengren, Crannogs: A study of people's interaction with lakes, with particular reference to Lough Gara in the north-west of Ireland (Dublin, 2002), 96.

${ }^{46}$ David Brown, personal communication.

${ }^{47}$ Plunkett et al., 'Environmental indifference?'.

${ }^{48}$ Brown and Baillie, 'Confirming the existence of gaps and depletions'.

49 Timpany, Monk and Power, 'Agricultural boom and bust in medieval Ireland'; Monk and Power, 'More than a grain of truth emerges from a rash of corn-drying kilns', 39. 
the major cultural change seen from the sixth century was facilitated by a rapid spread of Christianity following a series of closely-spaced environmental downturns that began in $\mathrm{AD}$ 536 (discussed later). ${ }^{50}$

Technological advances occurred with the introduction of the watermill from at least the early seventh century. ${ }^{51}$ A concentrated building phase of horizontal mills (AD 750850 ) - inferred from a rise in the number of dendrochronologically-dated sites from this time interval - is contemporary with an overall decline in corn-drying kiln numbers but possibly, according to Monk and Power, with an increase in potentially more efficient and larger keyhole type kilns (Fig. 1). ${ }^{52}$ Recently, Rynne has dismissed the significance of this seeming mill-building phase, arguing that the early texts indicate the existence of widespread mills in the seventh century, and pointing to the relative lack of Anglo-Norman mills in the archaeological record that conflicts with documentary evidence for their ubiquity. ${ }^{53}$

The changes in cereal-related structures support the notion of a shift in agricultural practices, with the AD 750-850 peak in horizontal mills argued by some to reflect increased grain production for an expanding population. ${ }^{54}$ Conversely, drawing on an extensive database of dated early medieval sites, Hannah and McLaughlin have proposed that populations peaked in the late seventh century, and declined steadily thereafter. ${ }^{55}$ However, the disparity between the seemingly industrial level of grain processing and a decrease in archaeological visibility may perhaps be explained at least in part by changing settlement patterns. It has been suggested that greater control of cereal production by the elite may have been a factor in the contraction of kiln numbers. ${ }^{56}$ Raised or platform raths - in which the enclosed area was artificially raised - emerged around the same time. These sites have been linked to an arable economy on the basis of their frequent occurrence close to high quality soils, and soon after their emergence, there is a decline in the construction of other rath

${ }^{50}$ Baillie, 'Patrick, comets and Christianity'.

${ }^{51}$ Colin Rynne, 'Some observations on the production of flour and meal in the early historical period', Journal of the Cork Historical and Archaeological Society 95 (1990), 20-9.

${ }^{52}$ Monk and Power, 'More than a grain of truth emerges from a rash of corn-drying kilns', 40.

${ }^{53}$ Colin Rynne, 'Technological change in the agrarian economy of early medieval Ireland: New archaeological evidence for the introduction of the coulter plough', Proceedings of the Royal Irish Academy 118C (2018), 37-66: 57; Colin Rynne, 'Technological continuity, technological "survival": The use of horizontal mills in western Ireland, c. 1632-1940', Industrial Archaeology Review 33 (2011), 96-105.

${ }^{54}$ Rynne, 'Some observations on the production of flour and meal in the early historical period'.

${ }^{55}$ Emma Hannah and Rowan McLaughlin, 'Long-term archaeological perspectives on new genomic and environmental evidence from early medieval Ireland', Journal of Archaeological Science 106 (2019), 23-8.

${ }^{56}$ Monk and Power, 'More than a grain of truth emerges from a rash of corn-drying kilns', 40. 
types. ${ }^{57}$ Variations in the agricultural economy are observed from the ninth century onwards, as pigs and sheep became more prominent in some areas while cattle appear to have declined in relative terms. ${ }^{58}$ These changes are evident across Ulster and the west of Ireland, suggesting a possible shift in the socio-political and economic regime at least at a regional level. ${ }^{59}$ The number of archaeological sites yielding archaeobotanical evidence for cereal cultivation increases between the seventh and tenth centuries, and greater diversity of crops is also observed from this time. ${ }^{60}$ McCormick proposes that these changes may be symptomatic of a shift away from a cattle-based economy towards one fuelled by surplus agricultural production. $^{61}$

Notwithstanding Rynne's objections, the available data imply that the erection of horizontal mills declined after AD 850, and dendrochronological evidence suggests that oak woodland began to regenerate from the mid-ninth century. ${ }^{62}$ The following century sees a decline in many facets of the archaeological record. A further gap in dendro-datable, oakbuilt structures occurred during the period AD 930-1010, ${ }^{63}$ and this is mirrored by a general lull in bog trackway constructions across Ireland. ${ }^{64}$ Despite some continuity of use into the high medieval period and beyond, ${ }^{65}$ in many areas the 'terminal decay' of raths as a settlement type appears to have begun around this time, ${ }^{66}$ and corn-drying kilns also decline. ${ }^{67}$ In view of the apparent fall-off in human activity during the tenth century inferred from some aspects of the archaeological record, a population crash has been proposed,

${ }^{57}$ T.R. Kerr, Early Christian settlement in north-west Ulster, British Archaeological Reports Series 430, (Oxford, 2007).

${ }^{58}$ Aidan O'Sullivan et al., Early medieval Ireland, AD 400-1100, the evidence from archaeological excavations, Royal Irish Academy Monographs (Dublin, 2013), 210.

${ }^{59}$ O'Sullivan et al., Early medieval Ireland, AD 400-1100, 210.

${ }^{60}$ Muriel McClatchie et al., 'Early medieval farming and food production: A review of the archaeobotanical evidence from archaeological excavations in Ireland', Vegetation History and Archaeobotany 24 (2015), 179-86.

${ }^{61}$ Finbar McCormick, 'Agriculture, settlement and society in early medieval Ireland', Quaternary International 346 (2014), 119-30: 128.

${ }^{62}$ Brown and Baillie, 'Confirming the existence of gaps and depletions'.

${ }^{63}$ Brown and Baillie, 'Confirming the existence of gaps and depletions'.

${ }^{64}$ Plunkett et al., 'Environmental indifference?'.

${ }^{65}$ Elizabeth Fitzpatrick, 'Native enclosed settlement and the problem of the Irish "ring-fort", Medieval Archaeology 53 (2009), 271-307.

${ }^{66}$ Kerr and McCormick, 'Statistics, sunspots and settlement', 499.

${ }^{67}$ Timpany, Monk and Power, 'Agricultural boom and bust in medieval Ireland'. 
attributed to the possible impact of a large-scale volcanic eruption, perhaps that of Eldgjá in Iceland, in the late AD 930s. ${ }^{68}$

\section{Reconstructing the climate of final prehistoric and early medieval Ireland}

The climate of the final centuries $\mathrm{BC}$ and first millennium $\mathrm{AD}$ has been characterised as part of the broader Subatlantic period (from $c .800 \mathrm{BC}$ ), which has traditionally been defined by cool summers, increased storminess and milder winters across north-west Europe.

Centennial-scale climatic reconstructions over the past few decades have, however, demonstrated that this definition is an oversimplification of the meteorological conditions for the period ${ }^{69}$ and have identified three main climatic shifts: the Roman Warm Period, ${ }^{70}$ the Dark Age Climatic Deterioration ${ }^{71}$ and the Medieval Warm Period. ${ }^{72}$ However, to assess the relationship between environmental and social change, regionally relevant climate records are crucial. We consider to what extent these phases are represented within Ireland by examining the available palaeoclimate records from across the island.

Irish palaeoclimate records include but one temperature reconstruction from southwest Ireland, in the form of oxygen isotope analyses from a speleothem record from Crag Cave, Co. Kerry. ${ }^{73}$ Furthermore, with chronological error margins of \pm 200 years for the end of the first millennium $\mathrm{AD},{ }^{74}$ the dating precision of this record is inadequate for identifying centennial and sub-centennial climate impacts on society. In contrast, the Belfast Oak

${ }^{68}$ Brown and Baillie, 'Confirming the existence of gaps and depletions'.

${ }^{69}$ P.G. Langdon, 'Reconstructing Holocene climate change in Scotland utilising peat stratigraphy and tephrochronology', unpublished PhD thesis, University of Southampton, 1999; Anthony Blundell, 'Late-Holocene multi-proxy climate records from Northern Britain and Ireland derived from raised peat stratigraphy', unpublished $\mathrm{PhD}$ thesis, University of Southampton, 2002; G.T. Swindles, Gill Plunkett and H.M. Roe, 'A multiproxy climate record from a raised bog in County Fermanagh, Northern Ireland: A critical examination of the link between bog surface wetness and solar variability', Journal of Quaternary Science 22 (2007), 667-79; G.T. Swindles et al., 'Centennial-scale climate change in Ireland during the Holocene', Earth Science Reviews 126 (2013), 300-20; M.J. Amesbury, 'Fine-resolution peat-based palaeoclimate records of the late-Holocene', unpublished $\mathrm{PhD}$ thesis, University of Southampton, 2008.

${ }^{70}$ H.H. Lamb, Climate: past present and future, 157.

${ }^{71}$ J.J. Blackford and F.M. Chambers, 'Proxy record of climate from blanket mires: Evidence for a Dark Age (1400BP) climatic deterioration in the British Isles', The Holocene 1 (1991), 63-7.

${ }^{72}$ H.H. Lamb, 'The early medieval warm epoch and its sequel', Palaeogeography, Palaeoclimatology, Palaeoecology 1 (1965), 13-37.

${ }^{73}$ Frank McDermott et al., 'Holocene climate variability in Europe: Evidence from $\delta^{18} \mathrm{O}$, textural and extension-rate variations in three speleothems', Quaternary Science Review 18 (1999), 1021-38; Frank McDermott, D.P. Mattey and Chris Hawkesworth, 'Centennial-scale Holocene climate variability revealed by a high-resolution speleothem $\delta^{18} \mathrm{O}$ record from SW Ireland', Science 294 (2001), 1328-31.

${ }^{74}$ McDermott et al., 'Holocene climate variability in Europe'; McDermott, Mattey and Hawkesworth, 'Centennial-scale Holocene climate variability'. 
Chronology is a precisely-dated dendrochronological archive that displays growth anomalies that reflect environmental stress during the trees' growing season (Fig. 2) ${ }^{75}$ as well as longerrun phases of woodland regeneration and dying-off. ${ }^{76}$ This chronology contributes to the recent Old World Drought Atlas (OWDA), a tree-ring derived model of annual and spatial hydroclimate variability (specifically, in summer season precipitation) across Europe during the last two millennia. ${ }^{77}$ The Atlas data can be tailored to provide a precisely-dated reconstruction of precipitation in Ireland.

Peat-based palaeohydrological records based on humification, plant macrofossils and/or testate amoebae analyses from ombrotrophic bogs have for some time formed the backbone of Irish palaeoclimate reconstructions for the last several millennia. These proxies can be employed to demonstrate shifts in bog surface wetness (BSW), the level of which reflects the complex interplay between temperatures and rainfall and their impact on bog hydrology. ${ }^{78}$ Essentially, wetter bog surfaces can result from increased rainfall and/or a reduction in surface water evaporation due to lower atmospheric temperatures; conversely drier bog surfaces arise due to decreased precipitation and/or higher atmospheric temperatures. Studies examining recent bog hydrology suggest that BSW in Atlantic Europe is more closely linked to changes in the summer precipitation deficit, that is, the moisture balance achieved specifically during the growing season by the combined effects of rainfall and surface water evaporation, the latter determined by temperature. ${ }^{79}$ Recently, Swindles and colleagues compiled palaeoclimate proxy records from across Ireland and performed a meta-analysis to examine centennial-scale climate variability during the last 5,000 years. ${ }^{80}$

\footnotetext{
${ }^{75}$ M.G.L. Baillie, A slice through time: Dendrochronology and precision dating (London, 1995).
}

${ }^{76}$ H.H. Leuschner et al., 'Subfossil European bog oaks: Population dynamics and long-term growth depressions as indicators of changes in the Holocene hydro-regime and climate', The Holocene 12 (2002), 695-706.

${ }^{77}$ E.R. Cook et al., 'Old World megadroughts and pluvials during the Common Era', Science Advances 1 (2015), e1500561.

${ }^{78}$ Blackford and Chambers, 'Proxy record of climate from blanket mires'; D.J. Charman, 'Summer water deficit variability controls on peatland water-table changes: Implications for Holocene palaeoclimate reconstructions', The Holocene 17 (2007), 217-27; Swindles et al., 'Centennial-scale climate change'.

${ }^{79}$ Charman, 'Summer water deficit variability controls on peatland water-table changes'; G.T. Swindles et al., 'A 4500-year proxy climate record from peatlands in the north of Ireland: the identification of widespread summer “drought phases”?', Quaternary Science Reviews 29 (2010), 1577-89.

${ }^{80}$ Swindles et al. 'Centennial-scale climate change'. 


\section{The Roman Warm Period}

The Roman Warm Period (c. 300 BC-AD 350) is generally described as a period of climatic amelioration across Europe coinciding with the pinnacle of the Roman Empire's expansion. ${ }^{81}$ Climate-proxy evidence from Europe suggests that favourable meteorological conditions enabled alpine pines to extend to higher altitudes, which coincided with a contraction of the Gepatschferner glacier. ${ }^{82}$ A variety of ocean sediment cores are also indicative of warmer sea temperatures between $c .400 \mathrm{BC}$ and $\mathrm{AD} 450,{ }^{83}$ and further evidence of a climatic improvement is displayed in the isotope record of the Greenland Ice Core Project (GRIP) ice core ${ }^{84}$ Chronologically, these conditions appear to have prevailed during the Irish cultural phases of the Developed Iron Age and the Late Iron Age.

In Ireland, speleothem-based temperature reconstructions from Crag Cave, Co. Kerry, indicate a shift towards warmer climatic conditions from c. 250 BC. ${ }^{85} \mathrm{BSW}$ records from Slieveanorra, Co. Londonderry, and Dead Island, Co. Antrim, show two phases of reduced water tables indicative of a drier/warmer climate $c .320 \mathrm{BC}-\mathrm{AD} 470,{ }^{86}$ while the palaeoenvironmental reconstruction from Glen West Bog, Co. Fermanagh, ${ }^{87}$ and Ardkill Moss, Co. Kildare, ${ }^{88}$ display comparable results. On the basis of their meta-analysis of Irish palaeoclimate data, Swindles and colleagues suggest that the period c. $300 \mathrm{BC}-\mathrm{AD} 400$ was mainly characterised by dry/warm conditions. ${ }^{89}$ This conclusion is supported by the OWDA

${ }^{81}$ Ting Wang, Donna Surge and Steven Mithen, 'Seasonal temperature variability of the Neoglacial (3300-2500 BP) and Roman Warm Period (2500-1600 BP) reconstructed from oxygen isotope ratios of limpet shells (Patella vulgata), northwest Scotland', Palaeogeography, Palaeoclimatology, Palaeoecology 317-8 (2012), 104-13.

${ }^{82}$ Kurt Nicolussi et al., 'Holocene tree-line variability in the Kauner Valley, Central Eastern Alps, indicated by dendrochronological analysis of living trees and subfossil logs', Vegetation History Archaeobotany 14 (2005), 221-34: 228.

${ }^{83}$ H.C. Hass, 'Northern Europe climate variations during late Holocene: Evidence from marine Skagerrak', Palaeogeography, Palaeoclimatology, Palaeoecology 123 (1996), 121-45; Jón Eiríksson et al., 'Variability of the North Atlantic Current during the last 2,000 years based on shelf bottom water and sea surface temperatures along an open ocean/shallow marine transect in western Europe', The Holocene 16 (2006), 1017-29; C.S. Andresen et al., 'Interactions between subsurface waters and calving of the Jakodshavn Isbræ during the late Holocene', The Holocene 21 (2010), 21124.

${ }^{84}$ Willy Tinner et al., 'Climatic change and contemporaneous land-use phases north and south of the Alps 2300 BC to 800 AD’, Quaternary Science Reviews 22 (2003), 1447-60.

${ }^{85}$ McDermott et al., 'Holocene climate variability in Europe'.

${ }^{86}$ Swindles et al., 'A 4500-year proxy climate record'.

${ }^{87}$ Swindles, Plunkett and Roe,, 'A multiproxy climate record'.

${ }^{88}$ Blundell, 'Late-Holocene multi-proxy climate records'; Anthony Blundell, D.J. Charman and K.E. Barber, 'Multi-proxy late Holocene peat records from Ireland: Towards a regional palaeoclimate curve', Journal of Quaternary Science 23 (2008), 59-71.

${ }^{89}$ Swindles et al., 'Centennial-scale climate change'. 
reconstructions that demonstrate generally drier conditions in Ireland in the first centuries $\mathrm{AD}$, particularly pronounced during the fourth century, but interrupted by a short, wet interval in the third century AD. ${ }^{90}$

Within these broader trends that may or may not have been perceptible at a generational timescale, certain individual years, or sets of years, have been singled out in the literature as representing particularly anomalous conditions that are more likely to have been notable within a human lifetime. The dendrochronological record indicates a period of shortlived environmental stress for Irish oaks at 207 BC that is matched in German oaks and North American bristlecone pines. ${ }^{91}$ Historical accounts from China and Egypt record this as a time of devastating famine and social upheaval, ${ }^{92}$ suggesting that whatever caused the trees stress - possibly a volcanic eruption, given the occurrence of large acid spikes in Greenland ice cores at this time - may also have had wider environmental and social repercussions. A similar series of tree growth anomalies, ice core acid layers and historical accounts of extreme weather signifying a global dust veil can be observed at $44-42 \mathrm{BC},{ }^{93}$ but the event is not evident in the few Irish oaks that span this period, or indeed in British timbers, ${ }^{94}$ perhaps implying that the British Isles were buffered from this downturn. Arguably, such events are too short-lived to be detectable in other, less well-resolved palaeoclimate records.

\section{The Dark Age Climatic Deterioration}

The majority of European climate proxies demonstrate a shift to wetter/cooler conditions in the mid-sixth century in a phase that has been named the Dark Age Climatic Deterioration. ${ }^{95}$ Temperature reconstructions from pine trees across Europe indicate cooler summer temperatures during the mid-sixth century, ${ }^{96}$ while a variety of tree species record a growth

\footnotetext{
${ }^{90}$ Cook et al., 'Old World megadroughts'.

${ }^{91}$ M.G.L. Baillie, 'Irish oaks record volcanic dust veils drama!', Archaeology Ireland 2, no. 2 (1988), 71-4; Baillie, 'Marking in marker dates'; Baillie, 'Great oaks from little acorns'.
}

${ }^{92}$ Baillie, 'Marking in marker dates'; Baillie, 'Great oaks from little acorns'; M.G.L. Baillie and Jonny McAneney, 'Tree ring effects and ice core acidities clarify the volcanic record of the first millennium', Climate of the Past Discussions 11 (2015), 105-14; Francis Ludlow and J.G. Manning, 'Revolts under the Ptolemies: A paleoclimatic perspective', in J.J. Collins and J.G. Manning (eds), Revolt and resistance in the ancient classical world and the Near East: The crucible of empire, Culture and History of the Ancient Near East Series (Leiden, 2016), 154-71.

${ }^{93}$ Baillie, 'Marking in marker dates'; Baillie, 'Great oaks from little acorns'; Michael Sigl et al., 'Timing and climate forcing of volcanic eruptions for the past 2,500 years', Nature 523 (2015), 543-9.

${ }^{94}$ David Brown, personal communication.

${ }^{95}$ Blackford and Chambers, 'Proxy record of climate from blanket mires'.

${ }^{96}$ K.R. Briffa et al., 'Fennoscandian summers from AD 500: Temperature changes on short and long timescales', Climate Dynamics 7 (1992), 111-9; Samuli Helama et al., 'The supra-long Scots pine tree-ring record for Finnish Lapland: Part 2, interannual to centennial variability in summer temperatures for 7500 years', The Holocene 12 (2002), 681-7. 
anomaly indicating stress on the trees during their growing season $c$. AD $540 .{ }^{97}$ European peatlands experienced a significant increase in $\mathrm{BSW},{ }^{98}$ while a rise in lake-levels across Europe also suggest the onset of wetter conditions. ${ }^{99}$ Until recently, the duration of the climate downturn was not well defined, with many peatland-based palaeohydrological records suggesting various timeframes for its end, ranging from $c$. AD 600-800. Using treering derived temperature reconstructions from the Alps and the Altai Mountains, Büntgen and colleagues have now identified a period of cooling that lasted from AD 536 to approximately $\mathrm{AD}$ 660, and have called this phase the 'Late Antique Little Ice Age'. ${ }^{100}$ They suggest that rapid climate deterioration may have triggered a series of political upheavals and migrations and may have been a factor in the spread of the Justinian Plague in the early 540s. The start of the cooling coincides with growth downturns first noted in the Belfast Oak dendrochronological series at AD 536 and AD 541. ${ }^{101}$ Baillie and McAneney's suggestion that these environmental downturns were the direct result of large-scale volcanic eruptions has been substantiated by the revised dating of the Greenland and Antarctic ice core records that attest volcanic events at these times. ${ }^{102} \mathrm{~A}$ downturn in solar output during the seventh century may also have impacted on climate, ${ }^{103}$ although the mechanisms and manifestation of such an impact are poorly understood.

${ }^{97}$ Baillie and Munro, 'Irish tree rings, Santorini and volcanic dust veils'; Briffa et al., 'Fennoscandian summers from AD 500: Temperature changes on short and long timescales', 111-9; Leuschner et al., 'Subfossil European bog oaks'; M.M. Naurzbaev et al., 'Summer temperatures in eastern Taimyr inferred from a 2427-year late-Holocene tree-ring chronology and earlier floating series', The Holocene 12 (2002), 727-36.

${ }^{98}$ Bent Aaby, 'Cyclic climatic variations in climate over the past 5,500 years reflected in raised bogs', Nature 263 (1976), 281-4; K.E. Barber, F.M. Chambers and Darrel Maddy, 'Late Holocene climatic history of northern Germany and Denmark: Peat macrofossil investigations at Dosenmoor, Schleswig-Holstein and Svanemose, Jutland', Boreas 33 (2004), 132-44; Uulle Sillasoo et al., 'Peat multi-proxy data from Männikjärve bog as indicators of late Holocene climate changes in Estonia', Boreas 36 (2007), 20-37; Amesbury, 'Fine-resolution peat-based palaeoclimate records of the late-Holocene'.

${ }^{99}$ Michel Magny, 'Holocene climate variability as reflected by mid-European lake-level fluctuations and its probable impact on prehistoric human settlements', Quaternary International 113 (2004), 65-79.

${ }^{100}$ Ulf Büntgen et al., 'Cooling and societal change during the Late Antique Little Ice Age from 536 to around 660 AD', Nature Geoscience 9 (2016), 231-6.

${ }^{101}$ Baillie and Munro, 'Irish tree rings, Santorini and volcanic dust veils'.

${ }^{102}$ Baillie and McAneney, 'Tree ring effects'; Sigl et al., 'Timing and climate forcing of volcanic eruptions'.

${ }^{103}$ C.A. Perry and K.J. Hsu, 'Geophysical, archaeological, and historical evidence support a solar-output model for climate change', Proceedings of National Academic Science 97 (2000), 12433-8. 
In Ireland, peatland records demonstrate a gradual shift to elevated water tables from the mid-sixth century, ${ }^{104}$ but due to a lack of chronological precision the exact timing of this event has been elusive. Mongan Bog, Co. Offaly, was the subject of three separate palaeohydrological investigations, all of which recorded increased BSW within this timeframe. ${ }^{105}$ Elevated water tables for the same period were observed at Letterfrack, Co. Galway, ${ }^{106}$ Cloonoolish Moss, Co. Galway ${ }^{107}$ and Fallahogy Bog, Co. Londonderry. ${ }^{108}$ Swindles and colleagues reported a trend towards wetter conditions in the north-east of Ireland from the seventh century, with a more distinct wet shift occurring at $c$. AD 770. ${ }^{109}$ More recently, Swindles and colleagues place the start of a widespread wet phase at $c$. AD 550, with wet conditions persisting until $c$. AD 800, although these conditions are not recorded at all sites for the same duration. ${ }^{110}$

The OWDA largely corroborates these changes, with extended wet phases evident between the mid-sixth and late seventh centuries and between the mid-eighth and mid-ninth centuries. ${ }^{111}$ The tree-ring data also highlight short phases of wetter (early fifth century) and drier (early eighth century) conditions not easily determined by the peatland records. These fluctuations are further supported by annalistic records that reveal a series of severe droughts from the mid-seventh to mid-eighth centuries, followed by a period of more frequent heavy snows and storms from the mid-eighth to early ninth centuries. ${ }^{12}$

\footnotetext{
${ }^{104}$ Swindles et al., 'Centennial-scale climate change'.

${ }^{105}$ C.J. Haslam, 'Late Holocene peat stratigraphy and climatic change - a macrofossil
} investigation from the raised mires of north western Europe', unpublished $\mathrm{PhD}$ thesis, University of Southampton, 1987; K.E. Barber, F.M. Chambers and Darrel Maddy, 'Holocene palaeoclimates from peat stratigraphy: Macrofossil proxy climate records from three oceanic raised bogs in England and Ireland', Quaternary Science Reviews 22 (2003), 521-39; V.A. Hall and Dmitri Mauquoy, 'Tephradated climate- and human-impact studies during the last 1500 years from a raised bog in central Ireland', The Holocene 15 (2005), 1086-93.

${ }^{106}$ Blackford and Chambers, 'Proxy record of climate from blanket mires'.

${ }^{107}$ Blundell, Charman and Barber, 'Multi-proxy late Holocene peat records from Ireland'.

${ }^{108}$ Amesbury, 'Fine-resolution peat-based palaeoclimate records of the late-Holocene'.

${ }^{109}$ Swindles et al., 'A 4500-year proxy climate record'; Kerr, Swindles and Plunkett, 'Making hay while the sun shines?'.

${ }^{110}$ Swindles et al., 'Centennial-scale climate change'.

${ }^{111}$ Cook et al., 'Old World megadroughts'.

${ }^{112}$ Kerr, Swindles and Plunkett, 'Making hay while the sun shines?'. 


\section{The Medieval Warm Period}

Towards the end of the first millennium AD, a climatic amelioration, widely known as the Medieval Warm Period ${ }^{113}$ or the Medieval Climatic Anomaly, ${ }^{114}$ appears to have occurred across Europe. Temperature reconstruction from Fennoscandian Scots pines suggest a warming trend from the mid-tenth century, ${ }^{115}$ while the evidence from European oak cohorts indicate mild and humid summers across central Europe between AD 700-1000. ${ }^{116}$ Various climate reconstructions from numerous ocean core sediments point to warming sea surface temperatures in the period between AD 950-1150. ${ }^{117}$ There is, however, a conflicting body of evidence that suggests not all areas experienced this climatic amelioration, with cooler conditions observed in Siberia during the tenth century ${ }^{118}$ and glacier advances in Switzerland and Norway. ${ }^{119}$ Further research has led to the suggestion that the North Atlantic area may have experienced increased storminess during this time. ${ }^{120}$

Temperature reconstructions from Crag Cave in south-west Ireland are suggestive of warmer temperatures in the closing centuries of the first millennium AD; however, the chronological precision of the record is poor for this period. ${ }^{121}$ Results from the Irish peatland records are variable. Some sites, such as Cloonoolish Moss, Co. Galway, and Ardkill Moss, Co. Kildare, register low water tables until the beginning of the tenth century prior to a rise in

${ }^{113}$ Lamb, 'The early medieval warm epoch and its sequel'.

${ }^{114}$ Scott Stine, 'Extreme and persistent drought in California and Patagonia during mediaeval time', Nature 369 (1994), 546-9.

${ }^{115}$ Briffa et al., 'Fennoscandian summers from AD500'.

${ }^{116}$ Büntgen et al., '2500 years of European climate variability'.

${ }^{117}$ Dierk Hebbeln et al., 'Late Holocene coastal hydrographic and climate changes in the eastern North Sea', The Holocene 16 (2006), 987-1001; Andresen et al., 'Interactions between subsurface waters'.

${ }^{118}$ Christophe Corona et al., 'Long-term summer (AD751-2008) temperature fluctuation in the French Alps based on tree-ring data', Boreas 40 (2011), 351-66.

119 Johann Stötter et al., 'Holocene palaeoclimatic reconstruction in northern Iceland: Approaches and results', Quaternary Science Reviews 18 (1999), 457-74; J.A. Matthews et al., 'Holocene glacier variations in central Jotunheimen, southern Norway based on distal glaciolacustrine sediment cores', Quaternary Science Reviews 19 (2000), 1625-47; Hanspeter Holzhauser, Michel Magny and H.J. Zumbuühl, 'Glacier and lake-level variations in west-central Europe over the last 3500 years', The Holocene 15 (2005), 789-801.

${ }^{120}$ Hass, 'Northern Europe climate variations'; Malgorzata Witak et al., 'Holocene North Atlantic surface circulation and climatic variability: evidence from diatom records', The Holocene 15 (2005), 85-96; A.K. Dugmore et al., 'The role of climate in settlement and landscape change in the north Atlantic Islands: An assessment of cumulative deviations in high-resolution proxy climate records', Human Ecology 35 (2007), 169-78.

${ }^{121}$ McDermott, Mattey and Hawkesworth, 'Centennial-scale Holocene climate variability'. 
BSW. ${ }^{122}$ Two independent investigations from Mongan Bog, Co. Offaly, gave conflicting results: Barber and colleagues record increased BSW from the Dark Age Climatic Deterioration until after AD 1000, ${ }^{123}$ while Hall and Mauquoy find drier/warmer conditions from the end of the ninth century. ${ }^{124}$ The compiled peatland records show a shift to warmer/drier conditions during the ninth century, though this is mainly evident in sites in the north and east. ${ }^{125}$ None of the Irish annals gives any entries for favourable meteorological conditions from AD 800-1000, though their emphasis is characteristically upon extreme weather, and there are numerous references to severe winters and storms during this interval. ${ }^{126}$ The OWDA provides the most compelling evidence for drier conditions that persist from the mid-ninth century until the twelfth century.

\section{Climate impacts on subsistence? An assessment of the pollen record}

Pollen records spanning the Late Bronze and Iron Ages in Ireland have recently been reviewed in order to discern patterns in landscape use as a backdrop to changes in the cultural record. ${ }^{127}$ Many pollen records reveal woodland clearance at $c .300 \mathrm{BC}$ that can be associated with the start of the Developed Iron Age. ${ }^{128}$ While this pattern was generally ubiquitous across the Irish landscape, the timing of the initial clearance was not synchronous, nor are there any signs of coherent spatial patterning where renewed farming first began. ${ }^{129}$ For example, an agricultural expansion occurred at Caheraphuca, Co. Clare, at c. $450 \mathrm{BC}^{130}$ but

${ }^{122}$ Blundell, Charman and Barber, 'Multi-proxy late Holocene peat records from Ireland'.

${ }^{123}$ Barber, Chambers and Maddy, 'Holocene palaeoclimates from peat stratigraphy'.

${ }^{124}$ Hall and Mauquoy, 'Tephra-dated climate- and human-impact studies'.

${ }^{125}$ Swindles et al., 'Centennial-scale climate change', Fig. 5.

${ }^{126}$ Kerr, Swindles and Plunkett, 'Making hay while the sun shines?'.

${ }^{127}$ Plunkett, 'Tephra-linked peat humification records'; Lisa Coyle McClung, 'The Late Iron Age Lull—not so Late Iron Age after all!', Emania 21 (2013), 73-83.

${ }^{128}$ C.J. Caseldine and Jackie Hatton, 'Early land clearance and wooden trackway construction in the third and fourth millennia BC at Corlea, Co. Longford', Proceedings of the Royal Irish Academy 96B (1996), 11-9; C.J. Caseldine and Ben Gearey, 'A multiproxy approach to reconstructing surface wetness changes and prehistoric bog bursts in a raised mire system at Derryville Bog, Co. Tipperary, Ireland', The Holocene 15 (2005), 585-601; Gill Plunkett et al., 'A multi-proxy palaeoenvironmental investigation of the findspot of an Iron Age bog body from Oldcroghan, Co. Offaly, Ireland', Journal of Archaeological Science 36 (2009), 265-77; Karen Molloy, Ingo Feeser and Michael O'Connell, 'A pollen profile from Ballinphuill Bog: Vegetation and land-use history', in Jim McKeon and Jerry O'Sullivan (eds), The quiet landscape: Archaeological and palaeoecological investigations on the M6 Galway to Ballinasloe national road scheme, National Roads Authority Scheme Monograph 15 (Dublin, 2014), 116-8.

${ }^{129}$ Plunkett, 'Socio-political dynamics in later prehistoric Ireland'.

${ }^{130}$ Karen Molloy and Michael O’Connell, 'Prehistoric farming in western Ireland: Pollen analysis at Caheraphuca, Co. Clare', in Shane Delaney et al., (eds), Borderlands. Archaeological 
clearances were not observed at Derryville Bog, Co. Tipperary, until the third century BC. ${ }^{131}$ Although the level of woodland clearance is generally quite modest, implying that farming was not particularly intensive, the pollen record is testament to a predominantly pastoralbased subsistence (inferred from the comparatively low representation of cereals in pollen records of this period) during the Developed Iron Age that is otherwise difficult to discern in the archaeological record. ${ }^{132}$ The pollen record associated with the bog body dubbed Oldcroghan Man shows that the deposition of this individual in the bog occurred as agriculture began to expand in the area surrounding Clonearl Bog, Co. Offaly, in the early third century $\mathrm{BC},{ }^{133} \mathrm{a}$ finding that does not seem symptomatic of a subsistence economy threatened by environmental stress contra some explanations for apparent sacrifices such as this. Notwithstanding the comparatively poor chronological precision and the temporal resolution of pollen records, there are currently no indications that this subsistence base changed in any appreciable way in the period following the $207 \mathrm{BC}$ oak growth anomaly.

Evidence for farming in the pollen record generally declines around the turn of the millennium, a phenomenon widely referred to the as the Late Iron Age Lull. ${ }^{134}$ The extent of woodland regeneration has been interpreted by some to signify a collapse of the subsistence economy and has led Weir to posit a severe population crash, ${ }^{135}$ potentially as a result of the 44-42 BC global volcanic dust veil. ${ }^{136}$ But while the majority of pollen records demonstrate this lull, there are notable exceptions, such as low levels of arable agriculture identified at Emlagh Bog, Co. Meath, ${ }^{137}$ and in the area surrounding Cornaher Lough, Co. Westmeath. ${ }^{138}$ Furthermore, recent research has demonstrated that the lull observed within the pollen records can be better characterised as a protracted shift, the onset of which varied

investigations along the route of the M18 Gort to Crusheen road scheme, National Roads Authority Scheme Monograph 9 (Dublin, 2012), 109-122.

${ }^{131}$ Caseldine and Gearey, 'A multiproxy approach to reconstructing surface wetness changes'.

${ }^{132}$ Note, however, that cereal pollen is generally poorly dispersed and is underrepresented in many pollen records.

${ }^{133}$ Plunkett et al., 'A multi-proxy palaeoenvironmental investigation of the findspot'.

${ }^{134}$ G.F. Mitchell, 'Littleton bog, Tipperary: An Irish agricultural record', Journal of the Royal Society of Antiquaries Ireland 95 (1965), 121-32.

${ }^{135}$ Weir, 'Dark ages and the pollen record'; D.A. Weir, 'A palynological study of landscape and agricultural development in County Louth from the second millennium $\mathrm{BC}$ to the first millennium AD', Discovery Programme Reports 2 (1995), 77-126.

${ }^{136}$ Baillie, 'Great oaks from little acorns'.

${ }^{137}$ Conor Newman et al., 'Interpretation of charcoal and pollen data relating to a late Iron Age ritual site in eastern Ireland: A holistic approach', Vegetation History and Archaeobotany 16 (2007), $349-65$.

${ }^{138}$ Alyson Heery, 'The vegetation history of the Irish midlands: Palaeoecological reconstructions of two lake sites adjacent to eskers', unpublished $\mathrm{PhD}$ thesis, Trinity College Dublin, 1998. 
considerably between approximately $200 \mathrm{BC}$ and $\mathrm{AD} 200 ;{ }^{139}$ its diachronic nature, spanning many generations of Iron Age society, renders it highly unlikely to have been triggered by any single rapid or extreme event. Indeed, the lull seems to have endured across a relatively dry period but it cannot presently be established if such conditions were in any way a deterrent to cultivation or a facilitator of alternative subsistence practices. Regardless, the growing body of pollen evidence suggests that the lull represents a gradual shift in land-use that began within the Developed Iron Age.

For the most part, evidence for human activity in the pollen record remains limited, but not entirely invisible, through much of the Late Iron Age. Many pollen records show signs of renewed farming activity from $c$. AD 200-300, ${ }^{140}$ coinciding, it would seem, with an increase in the numbers of recorded corn-drying kilns, ${ }^{141}$ though the scale of arable production suggested by the pollen evidence is by no means intensive at this time. The third century wet-shift indicated by the OWDA illustrates a possible climatic incentive for the wider uptake of corn-drying facilities, but the archaeological evidence lacks the chronological resolution needed to scrutinise this relationship. Cereals can of course be dried by other means such as sheaf-burning, ${ }^{142}$ as they must have been before kilns began to be constructed, even when wetter conditions prevailed. The development of kilns need not therefore have been a direct response to climate change, but may simply reflect exposure to a novel technology, possibly through contacts with Roman Britain. Rye too may have been introduced around this time, with Secale cereale pollen (Fig. 3) recorded from the first century AD, and more widely from the fourth century (Fig. 4), coinciding with what seems to be a second wave of Romano-British influences. The combined archaeological and palaeoenvironmental evidence highlights a gradual economic and social change within the Late Iron Age that was possibly stimulated by contacts with, and perhaps migrants from, the Roman world as early as the first century AD during a period of relatively dry conditions, and again but with wider impact in the fourth and fifth centuries.

The post-Late Iron Age resurgence of farming clearly begins prior to the early medieval period and the introduction of Christianity. Only in the west of Ireland do clearances certainly post-date the mid-fifth century. ${ }^{143}$ The pollen record shows that

${ }^{139}$ Coyle McClung, 'The Late Iron Age Lull'.

${ }^{140}$ Gill Plunkett, 'Pollen analysis and archaeology in Ireland', in Eileen Murphy and N.J. Whitehouse (eds), Environmental Archaeology in Ireland (Oxford, 2007), 221-40; Carlos Chique, Karen Molloy and A.P. Potito, 'Mid-late Holocene vegetational history and land-use dynamics in County Monaghan, northeastern Ireland - the palynological record of Lough Muckno', Journal of the North Atlantic 32 (2017), 1-24.

${ }^{141}$ Timpany, Monk and Power, 'Agricultural boom and bust in medieval Ireland'; Monk and Power, 'More than a grain of truth emerges from a rash of corn-drying kilns'; Monk and Power, 'Casting light from the fires of corn-drying kilns on the Later Irish Iron Age'.

${ }^{142}$ Rynne, 'Some observations on the production of flour and meal in the early historical period'.

${ }^{143}$ Lisa Coyle McClung, 'A palynological investigation of land-use patterns in first millennium AD Ireland', unpublished PhD thesis, Queen's University Belfast, 2012, 201. 
agriculture was well-established in some areas before the founding of local monasteries, ${ }^{144}$ suggesting that the Church was not the main, or at least not the initial, driver of the wider economy. Vegetation reconstructions at a number of sites in Ulster and Leinster demonstrate a short downturn in farming, particularly in arable representation, following initial signs of land clearance, although this is by no means a universal phenomenon. ${ }^{145}$ For example, a decline in the mixed subsistence economy at Lake View, Co. Down, lasted around a century, ${ }^{146}$ and a similar interruption occurred at Cornaher Lough, Co. Westmeath. ${ }^{147}$ At Garry Bog, Co. Antrim, and Lake View, Co. Down, the decline commences between the midfifth to mid-sixth centuries AD, but the dating at other sites is less precise and age estimates span the period AD 350-1100. ${ }^{148}$ This phase of reduced farming would seem to straddle the period in which raths emerge. In view of the dating uncertainty, it is conceivable that a disruption to or shift within the subsistence economy around this time was triggered by the two extreme events recorded by Irish oaks at AD 536 and AD 540, or by the shift towards wetter conditions indicated by the OWDA data for Ireland, but the chronological resolution of the pollen records is simply insufficient to determine the precise timing of the land-use change and establish such a correlation. At Mongan Bog, Co. Offaly, however, from which there exists a combined palynological and climate proxy record, a decline in farming indicators at this time coincides with a shift to drier bog surfaces. ${ }^{149}$ More such integrated records are required to elucidate the relationship between climate and land-use changes.

The main rath building phase, $\mathrm{AD} 550-750$, therefore transpired against a background of potentially inclement climate and spatially variable degrees of land clearance and farming. By the mid-eighth to early ninth centuries, some sites display a distinct expansion in mixed agriculture with increased emphasis on arable cultivation, while others go into decline. Sites such as Monteith's Lough, Co. Down, ${ }^{150}$ Killymaddy Lough, Co. Tyrone, ${ }^{151}$

${ }^{144}$ V.A. Hall, 'The vegetation history of monastic and secular sites in the midlands of Ireland over the last two millennia', Vegetation History and Archaeobotany 15 (2005), 1-12.

${ }^{145}$ Coyle McClung, 'A palynological investigation of land-use patterns in first millennium AD Ireland', 203.

${ }^{146}$ Coyle McClung, 'A palynological investigation of land-use patterns in first millennium AD Ireland', 182.

${ }^{147}$ Heery, 'The vegetation history of the Irish midlands'.

${ }^{148}$ Coyle McClung, 'A palynological investigation of land-use patterns in first millennium AD Ireland', 182.

${ }^{149}$ Hall and Mauquoy, 'Tephra-dated climate- and human-impact studies'.

${ }^{150}$ Coyle McClung, 'A palynological investigation of land-use patterns in first millennium AD Ireland'.

${ }^{151}$ K.R. Hirons, 'Palaeoenvironmental investigations in east Co. Tyrone, Northern Ireland', unpublished PhD thesis, Queen's University Belfast, 1984. 
Abbeyknockmoy, Co. Galway, ${ }^{152}$ Red Bog, Co. Louth, ${ }^{153}$ and Barrees on the Beara Peninsula, Co. Cork, ${ }^{154}$ display land clearances on an unprecedented scale, which continued into the second millennium AD, and this evidence is difficult to reconcile with Hannah and McLaughlin's proposed population decline. ${ }^{155}$ The timing of this expansion can be refined at several sites where the 'AD860B' tephra has been recorded (Fig. 5). This tephra is now known to correspond to the White River Ash (Eastern Lobe) from Mount Churchill, Alaska, ${ }^{156}$ and has been dated in Greenland ice cores to AD 852/3 \pm 1 on the NS1-2011 ice core timescale. ${ }^{157}$ In the pollen record, an intensification of farming, including a peak in cereal production can be seen to occur in the century before this tephra was deposited on the bogs. The timing of this shift overlaps with the increasing frequency of severe weather conditions reported by the annalists from the mid-eighth and ninth centuries. ${ }^{158}$ The coincidence of the two changes does not certainly prove cause-and-effect, but it can now be demonstrated that the peak in horizontal mill construction (inferred from the dendrochronologically dated sites) and the putative shift to larger, more efficient, if fewer, corn-drying kilns (as proposed by Monk and Power) ${ }^{159}$ was associated with an intensification of cereal cultivation, and that these changes occurred against the backdrop of an increasingly harsh climate, as discussed earlier. Intensive land-use continued until the mid-ninth century and may have impacted on the availability of mature oaks for construction purposes, as reflected in the dendrochronological record.

Following the AD860B tephra, at sites such as at Fallahogy, Co. Londonderry, Ballyscullion, Co. Antrim, and Cloonoolish Moss, Co. Galway, farming declines, but does not cease. ${ }^{160}$ Elsewhere, such as at Clonfert, Co. Galway (Fig. 6), Garry Bog, Co. Antrim, and

${ }^{152}$ S.H. Lomas-Clarke and K.E. Barber, 'Palaeoecology of human impact during the historic period: Palynology and geochemistry of a peat deposit at Abbeyknockmoy, Co. Galway, Ireland', The Holocene 14 (2004), 721-31.

${ }^{153}$ Weir, 'A palynological study of landscape and agricultural development in County Louth'.

${ }^{154}$ Anette Overland and Michael O'Connell, 'Fine-spatial palaeoecological investigations towards reconstructing late Holocene environmental change, landscape evolution and farming activity in Barrees, Beara Peninsula, southwestern Ireland', Journal of the North Atlantic 1 (2008), 37-73.

${ }^{155}$ Hannah and McLaughlin, 'Long-term archaeological perspectives'.

${ }^{156}$ B.J.L. Jensen et al., 'Transatlantic distribution of the Alaskan White River ash', Geology 42 (2014), 875-8.

${ }^{157}$ S.E. Coulter et al., 'Holocene tephras highlight complexity of volcanic signals in Greenland ice cores', Journal of Geophysical Research - Atmospheres 117 (2012), D21303; Sigl et al., 'Timing and climate forcing of volcanic eruptions'.

${ }^{158}$ Kerr, Swindles and Plunkett, 'Making hay while the sun shines?'.

${ }^{159}$ Monk and Power, 'More than a grain of truth emerges from a rash of corn-drying kilns', 40.

${ }^{160}$ V.A. Hall, J.R. Pilcher and F.G. McCormac, 'Tephra-dated lowland landscape history of the north of Ireland, AD 750-1150', New Phytologist 125 (1993), 193-202; Plunkett, unpublished data. 
Emlagh Bog, Co. Meath, farming appears to have continued at the same level as before. ${ }^{161}$ Like the palaeoclimate record, then, the pollen data reveal spatial variability towards the end of the millennium, and there currently appears to be little evidence to support the suggestion of an environmentally-triggered downturn in human activity in the tenth century. The building gap identified by Brown and Baillie in the dendro-dated archaeological record cannot therefore be accounted for simply by a widespread population decline.

\section{Discussion}

This paper aimed to consider the relationship between cultural and environmental change in final prehistoric and early medieval Ireland, specifically with respect to some of the main examples offered in the literature that associate climatic and societal change. Despite the difficulties of evaluating short-term, but potentially severe, environmental events in all but the most highly resolved palaeoenvironmental records, we find little convincing evidence of cultural collapse during this time that might have been prompted by environmentally-driven perturbation of the subsistence base (Fig. 7). Recent archaeological research has clearly shown that in the Late Iron Age the island was certainly not depopulated, debunking hypotheses of an environmentally-triggered demographic crisis. ${ }^{162}$ Rather, we can see that there was widespread activity represented by mainly ephemeral archaeological remains and an increasing body of evidence for interactions with Roman Britain. It may, therefore, have been the absence of long-term settlement and fixed agriculture that prompted the decline in the visibility of farming in many pollen records that we know as the Late Iron Age Lull. It is perhaps particularly pertinent that the Late Iron Age Lull is time-transgressive and in some places begins within the Developed Iron Age, negating the likelihood of any single environmental trigger, and instead increasing the prospect that this was a more gradual, socially-determined process ${ }^{163}$ involving both economic and political re-organisation. Although none of the palaeoecological proxy records from Ireland can match the dendrochronological record or tree-ring-derived climate reconstructions for their chronological resolution, we observe no firm indications of long-term repercussions on the subsistence economy of the environmental events in 207 BC or 44-42 BC. Broadly speaking, the decline of large-scale communal endeavours and farming in the Developed Iron Age took place during the Roman Warm Period, when drier conditions appear usually to have prevailed in Ireland, and although wetter periods did occur, it is difficult to see climate change as a driver in the seeming breakdown of large-scale socio-political power structures over this extended period. In many places, the resumption of farming on a scale perceptible in pollen records, marking the end of the Late Iron Age Lull, broadly coincides with a growing body of

${ }^{161}$ Coyle McClung, 'A palynological investigation of land-use patterns in first millennium AD Ireland', Fig. 7.1; Anette Overland and Michael O'Connell, 'New insights into late Holocene farming and woodland dynamics in western Ireland with particular reference to the early medieval horizontal watermill at Kilbegly, Co. Roscommon', Review of Palaeobotany and Palynology 163 (2011), 205-26.

${ }^{162}$ Weir, 'Dark ages and the pollen record'.

${ }^{163}$ Coyle McClung, 'A palynological investigation of land-use patterns in first millennium AD Ireland; Coyle McClung, 'The Late Iron Age Lull'. 
archaeological evidence (i.e. corn-drying kilns) for an increase in cereal production from at least the third century AD. In view of the seemingly strong spatial relationship between the earliest corn-drying kilns and Roman material, a social stimulus-be that from migration, trade and/or other forms of contact-seems a more plausible explanation for the transition to enclosed settlements and increased cereal production that takes place at this time.

The next major cultural change - the dawn of the early medieval period - is traditionally dated to the fifth century $\mathrm{AD}$, but the most conspicuous aspects of the archaeological record appear a century or more later. We find that the start of this period shows continuity from the final Late Iron Age, at least in terms of land-use and subsistence economy as reflected in the pollen record. In parts of Ulster and Leinster, however, the nature and intensity of farming falter during the middle of the first millennium AD, broadly coinciding with the Dark Age Climatic Deterioration in the mid-sixth century. ${ }^{164}$ Further research that combines palaeoclimate and palynological reconstructions is needed to establish the relationship, if any, between these changes. Certainly, it would seem that the characteristic features of early medieval Ireland, such as raths and ecclesiastical settlements, expanded after this time. ${ }^{165}$ The pollen record reveals open, pastoral habitats, and it may be at this time that the cow-based wealth system indicated by the later law tracts came to the fore. McCormick has argued that the ringfort emerged as a defence against increased cattleraiding, precisely because of the value of cows. ${ }^{166}$

The full extent of land under cultivation is difficult to gauge from pollen records, but arable indicators become a more consistent and noticeable feature from the mid-first millennium AD. Cereal production increases in importance by the mid-eighth to ninth centuries, evidenced by a proliferation of horizontal mills and perhaps more efficient corndrying kilns, as well as the pollen record, and the archaeological record points to an industrious, resourceful society. Kerr and colleagues ${ }^{167}$ hypothesised that the shift to increased cultivation may have been an adaptation to a worsening climate and its effect on the cattle economy, a theory that awaits further, in-depth analysis through the palaeoenvironmental record. Climate may not have been the only, or even the principal, catalyst for this shift, however. McCormick has highlighted that the availability of suitable grazing serves as a limiting factor in the accumulation of wealth; eventually, elites needed to find an alternative currency and a move towards greater cereal production and the agricultural surplus it could facilitate may have enabled them to partake in exchanges along wider,

\section{AD Ireland'.}

${ }^{164}$ Coyle McClung, 'A palynological investigation of land-use patterns in first millennium

${ }^{165}$ Warner, 'Tree-rings, catastrophes and culture in Early Ireland', 19.

${ }^{166}$ Finbar McCormick, 'Cows, ringforts and the origins of Early Christian Ireland', Emania 13 (1995), 33-7.

${ }^{167}$ Kerr, Swindles and Plunkett, 'Making hay while the sun shines?'. 
regional networks. ${ }^{168}$ Further incentive for a move away from a cattle-dominated economy may have been the emergence of silver as a currency. ${ }^{169}$

A construction gap during the tenth century seems puzzling and prompted Brown and Baillie to consider if a lack of building was linked to a possible environmental downturn. ${ }^{170}$ They point to a series of growth anomalies in North American and Mongolian pines in the 930s that indicate severe growing conditions and which have been variously attributed to the eruption of Eldgjá, now dated by ice core chronology to AD 939. ${ }^{171}$ Whether or not extreme weather was manifest in Ireland at these times or impacted on human activity in the shortterm, certain pollen records demonstrate that intensive land-use and human activity continued, despite the absence of oak-built constructions, during this period. The hiatuses in construction could alternatively be explained by an over-exploitation of the woodlands following decades of intensive building in the previous century.

\section{Conclusions}

All too often, cultural changes, particularly those involving a shift to a more obscure archaeological record in which evidence for structures and other categories of material culture is less visible, are readily interpreted in terms of system collapse. Increasingly, yet harking back to modes of thinking in the earlier twentieth century, theories of environmentally-driven cultural changes are propounded, perhaps themselves stimulated by on-going concerns about current climate change and its potential future social impacts. ${ }^{172} \mathrm{In}$ this paper, we have critiqued the relationship between past climate change and perceived cultural change during the final prehistoric and early medieval periods. Ireland is endowed with extensive peatlands and lakes that have yielded invaluable records of past climate and past vegetation change. Using these records, it is possible to reconstruct general climate trends over extended periods, and to evaluate the impact of climate conditions on the subsistence economy, thus constructing an important bridge with the archaeological record.

Although we cannot in these records identify sub-decadal environmental events, such as those suggested by the tree-ring record, we can investigate if such events had longer-term repercussions on subsistence strategies. We find that the pollen record concords well with the archaeological record in terms of reflecting the fluctuating importance of cereal cultivation and pasture, and that for the most part these fluctuations appear to be socially-driven. Some potential climate impact may have been experienced in the mid-first millennium, giving rise to a shift in emphasis towards pastoral farming. The outcome, however, is not one of social collapse, but rather a new socio-political structure built upon cattle ownership. Further

${ }^{168}$ Finbar McCormick, 'The decline of the cow: Agricultural and settlement change in early medieval Ireland', Peritia 20 (2008), 210-225; McCormick, 'Agriculture, settlement and society in early medieval Ireland'.

\footnotetext{
${ }^{169}$ McCormick, 'Agriculture, settlement and society in early medieval Ireland', 28.

${ }^{170}$ Brown and Baillie, 'Confirming the existence of gaps and depletions'.

${ }^{171}$ Sigl et al., 'Timing and climate forcing of volcanic eruptions'

${ }^{172}$ Butzer, 'Collapse, environment, and society'.
} 
climate changes in the late eighth century may have fostered an economic adaptation that undermined the existing cow-orientated wealth system. On balance, however, it was probably internal and external politics that sowed the seed for a new socio-economic power base that stimulated changes in settlement types and the farming economy, with a greater emphasis on arable in many areas of Ireland. In short, though extreme weather anomalies will almost certainly have adversely impacted the populations who experienced them, the available evidence suggests that in the longer-term, climate trends played no major, or certainly not a detrimental, role in determining cultural evolution during the final prehistoric and early historical periods.

\section{Acknowledgments}

The authors wish to thank Brian Sloan for making available the photograph of the Tullahoge corn-drying kiln, and David Brown for supplying the image of the oak growth anomaly as well as his comments on the dendrochronological record. 
TABLE 1 - Outline of the main cultural events in the Developed to Late Iron Age and early medieval period that have been attributed to climate change

\begin{tabular}{|l|l|l|l|}
\hline Cultural event & Timing & Symptoms & Suggested environmental cause* \\
\hline $\begin{array}{l}\text { Flurry of large-scale } \\
\text { constructions during the } \\
\text { Developed Iron Age }\end{array}$ & $150-95 \mathrm{BC}$ & $\begin{array}{l}\text { Social/ideological upheaval leading to } \\
\text { construction of ritual and defensive sites } \\
\text { such as Navan and the Dorsey }\end{array}$ & $\begin{array}{l}\text { Volcanic event at 207 BC, aggravated } \\
\text { by further dust-veil event at 44-42 BC }\end{array}$ \\
\hline Late Iron Age Lull & $\begin{array}{l}\text { 200/100 BC-early } \\
\text { centuries AD }\end{array}$ & $\begin{array}{l}\text { Widespread forest regeneration; absence } \\
\text { of conspicuous archaeological record }\end{array}$ & $\begin{array}{l}\text { Depopulation following extreme and } \\
\text { rapid climate change }\end{array}$ \\
\hline $\begin{array}{l}\text { Start of early medieval } \\
\text { period proper }\end{array}$ & Mid-sixth century AD & $\begin{array}{l}\text { Spread of Christianity, surge in building } \\
\text { activity }\end{array}$ & $\begin{array}{l}\text { Dust-veil events at AD 536 and 540, } \\
\text { contributing to spread of plague }\end{array}$ \\
\hline Tenth century decline & Tenth century AD & Building gap in oak chronology & Volcanic eruption \\
*See text for references & \multicolumn{2}{|l}{} \\
\hline
\end{tabular}

* See text for references 


\section{Figures}

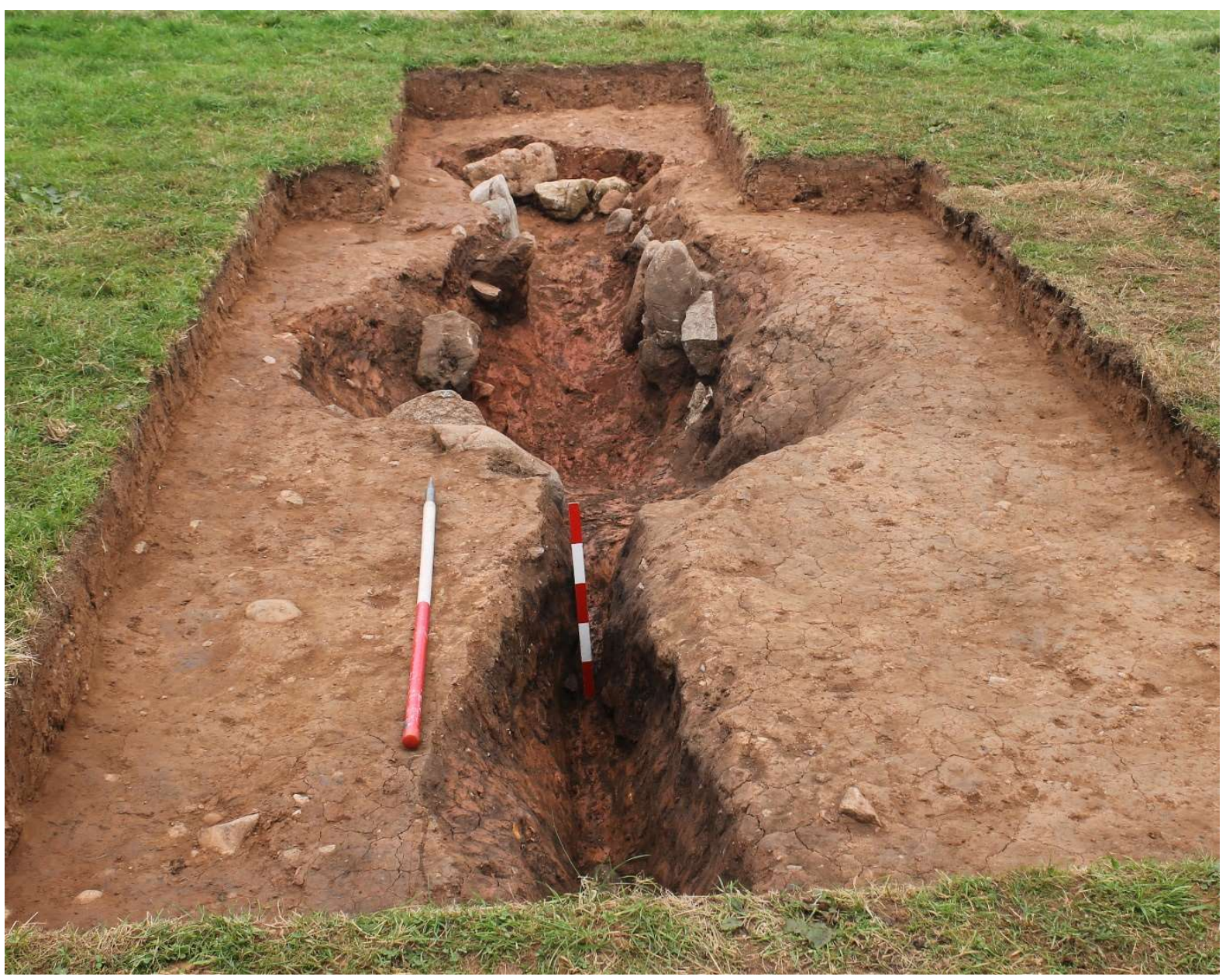

FIG. 1-Key-hole type corn-drying kiln at Tullahoge, Co. Tyrone, dated to the eight to tenth centuries (Photograph: B. Sloan). 


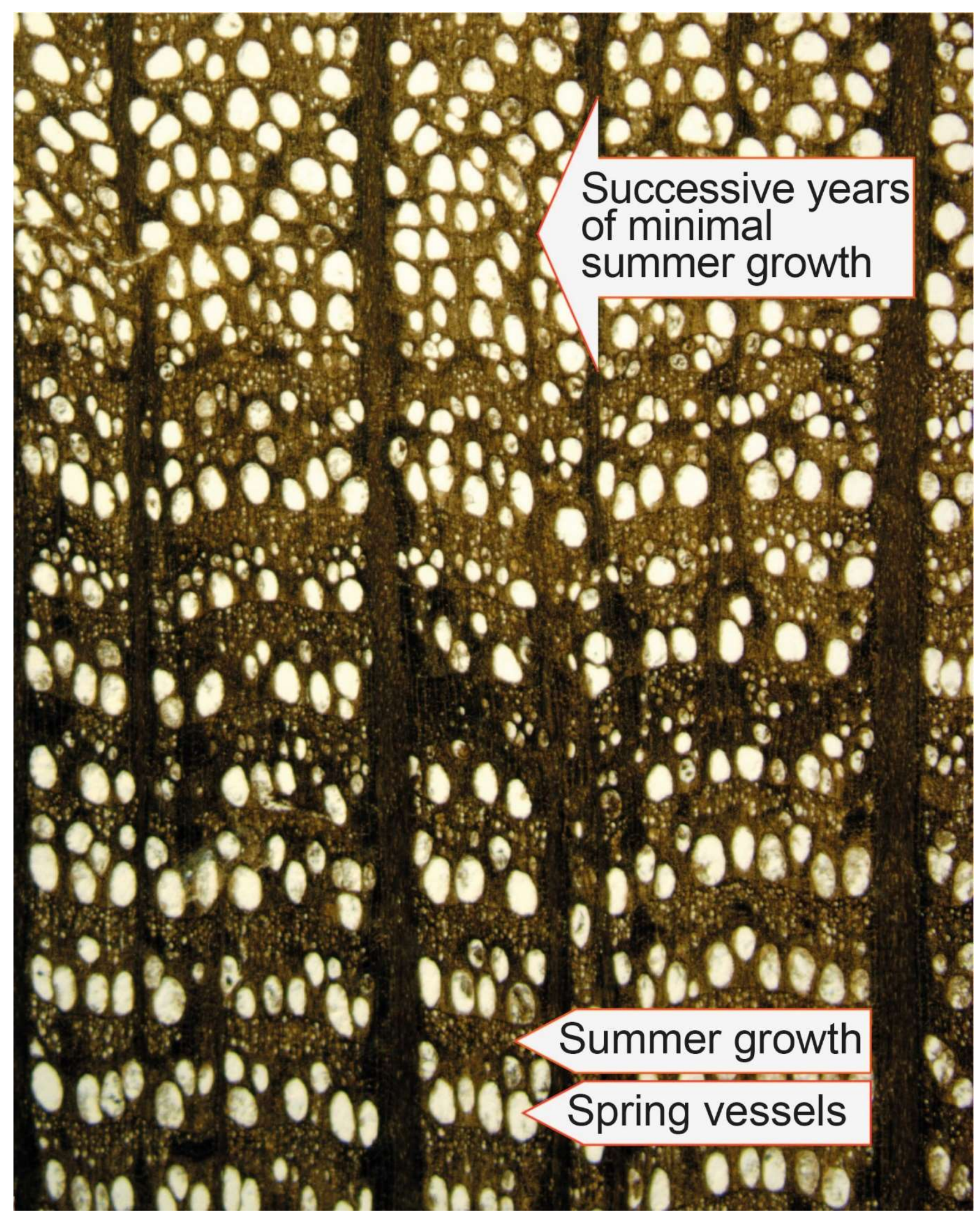

FIG. 2-Detail of oak timber, showing annual growth rings defined by spring vessels and summer growth. A growth anomaly (here dating to AD 540) is characterised by closely spaced series of spring vessels with relatively little summer wood, indicating poor growing conditions in successive years. 


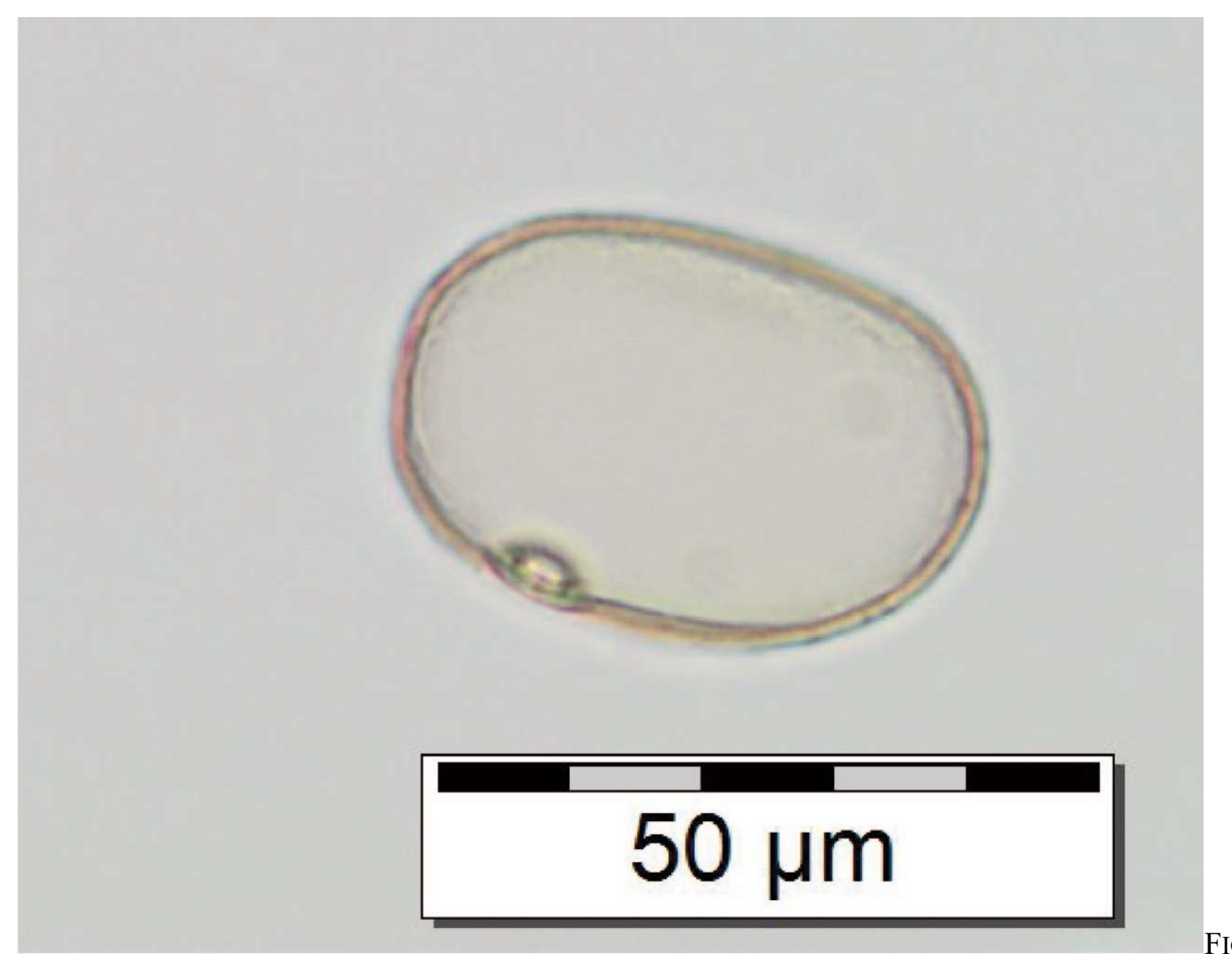

FIG.

3-A pollen grain from Secale cereale (rye). This cereal pollen is easily distinguished from wild and other domesticated grasses by its large size and the positioning of its pore (bottom left) towards the side of the grain. 


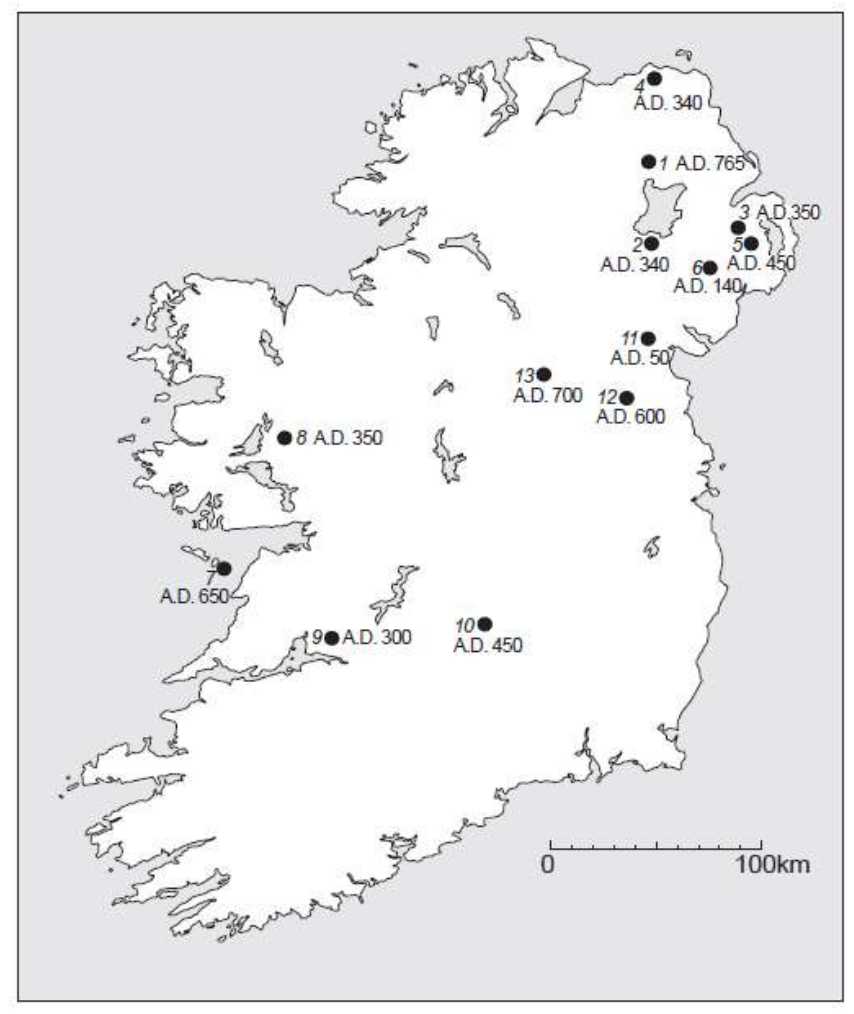

FIG. 4-Distribution of pollen sites showing evidence for Secale pollen in the first millennium AD (based on published data). 1. Ballyscullion East Bog (V.A. Hall, J.R. Pilcher and F.G. McCormac, 'Tephra-dated lowland landscape history of the north of Ireland, AD 750-1150', New Phytologist 125 (1993), 193-202); 2. Loughnashade (D.A. Weir, 'Dark ages and the pollen record', Emania 11 (1993), 21-30); 3. Long Lough (Valerie Hall, 'Recent landscape history from a Co. Down lake deposit', New Phytologist 115 (1990), 377-83); 4. Garry Bog (Lisa Coyle McClung, 'A palynological investigation of land-use patterns in first millennium AD Ireland', unpublished $\mathrm{PhD}$ thesis, Queen's University Belfast, 2012); 5. Lake View (Coyle McClung, 'A palynological investigation of land-use patterns in first millennium AD Ireland'); 6. Monteith's Lough (Coyle McClung, 'A palynological investigation of land-use patterns in first millennium AD Ireland'); 7. An Loch Mór (Karen Molloy and Michael O'Connell, 'Holocene vegetation and land-use dynamics in the karstic environment of Inis Oírr, Aran Islands, western Ireland: Pollen analytical evidence evaluated in light of the archaeological record', Quaternary International 113 (2004), 41-64); 8. Lough Fark (J.L. Fuller, 'Past vegetation and land-use dynamics in Mayo Abbey, central Mayo', Archaeology Ireland 16 (3) (2002), 20-23); 9. Mooghaun (Karen Molloy, 'Holocene vegetation and land-use history at Mooghaun, south-east Clare, with particular reference to the Bronze Age', in E. Grogan (ed.), The north Munster project Volume 1: The later prehistoric landscape of south-east Clare, Discovery Programme Reports (Bray, 2002), 255-301); 10. Derryville Bog (V.A. Hall, 'The vegetation history of monastic and secular sites in the midlands of Ireland over the last two millennia', Vegetation History and Archaeobotany 15 (2005), 1-12); 11. Red Bog (D.A. Weir, 'A palynological study of landscape and agricultural development in County Louth from the second millennium BC to the first millennium AD', Discovery Programme Reports 2 (1995), 77-126); 12. Emlagh Bog (Conor Newman et al., 'Interpretation of charcoal and pollen data relating to a late Iron Age ritual site in eastern Ireland: A holistic approach', Vegetation History and Archaeobotany 16 (2007), 349-65); 13. Derragh Bog (A.G. Brown et al., 'Vegetation, landscape and human activity in midland Ireland: Mire and lake records from Lough Kinale-Derragh Lough area, central Ireland', Vegetational History and Archaeobotany 14 (2005), 81-98). 


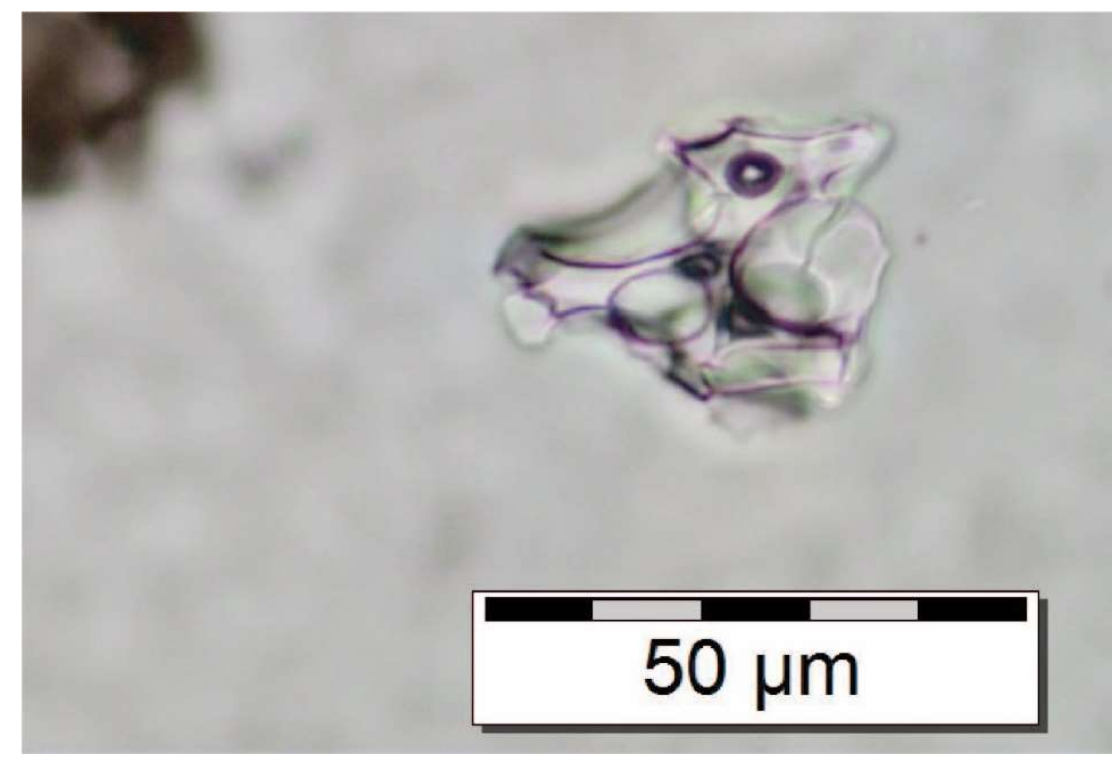

FIG. 5-Tephra (volcanic ash) shard from the 'AD860B' tephra from Churchill, Alaska. This tephra, erupted during the winter of $A D 852 / 3 \pm 1$, is widely found in Irish peat and lake sediments. 


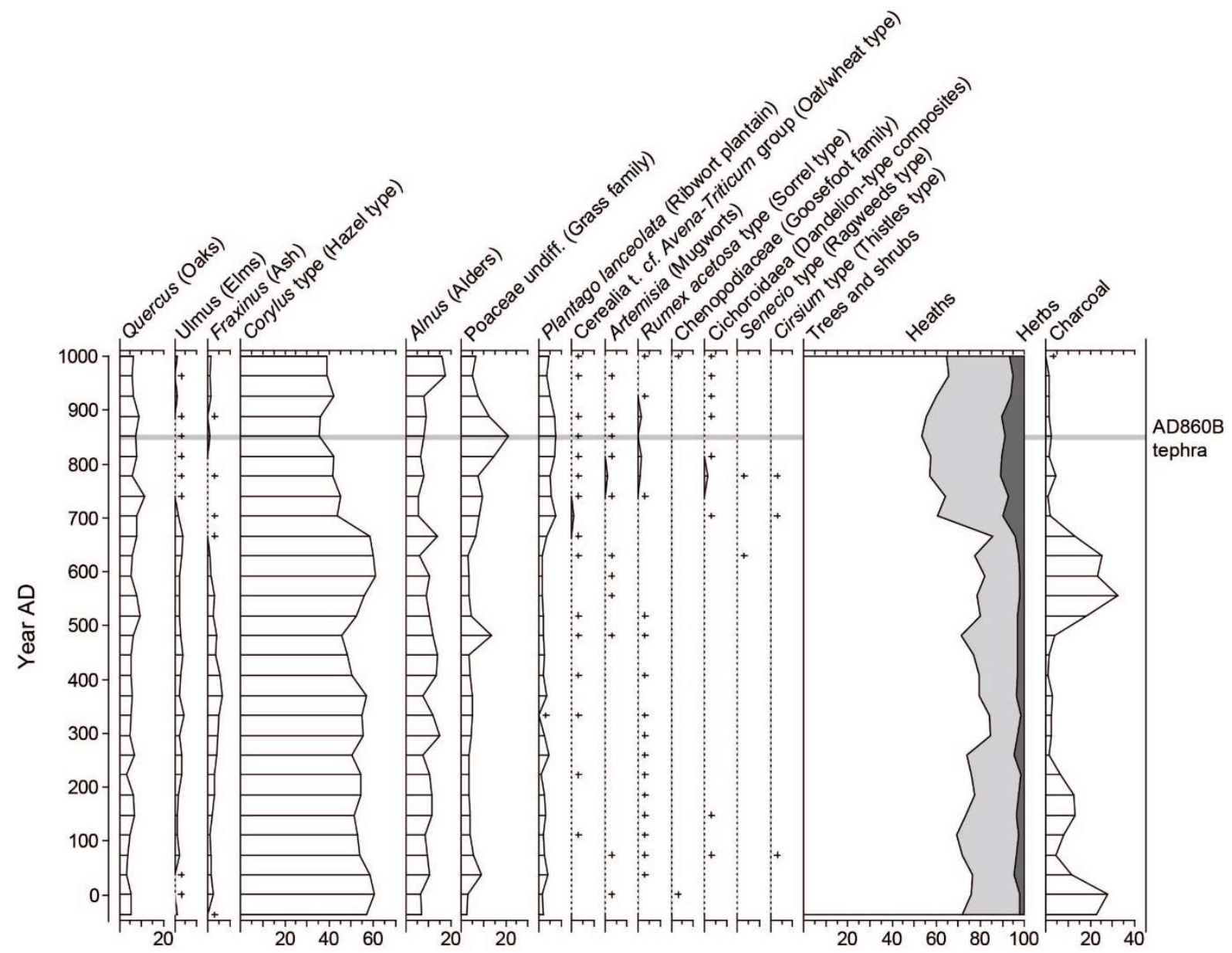

FIG. 6-Illustrative percentage pollen diagram from Clonfert, Co. Galway, based on data in Valerie Hall, 'The vegetation history of monastic and secular sites in the midlands of Ireland over the last two millennia', Vegetation History and Archaeobotany 15 (2006), 1-12. + indicates percentages $<1 \%$. 


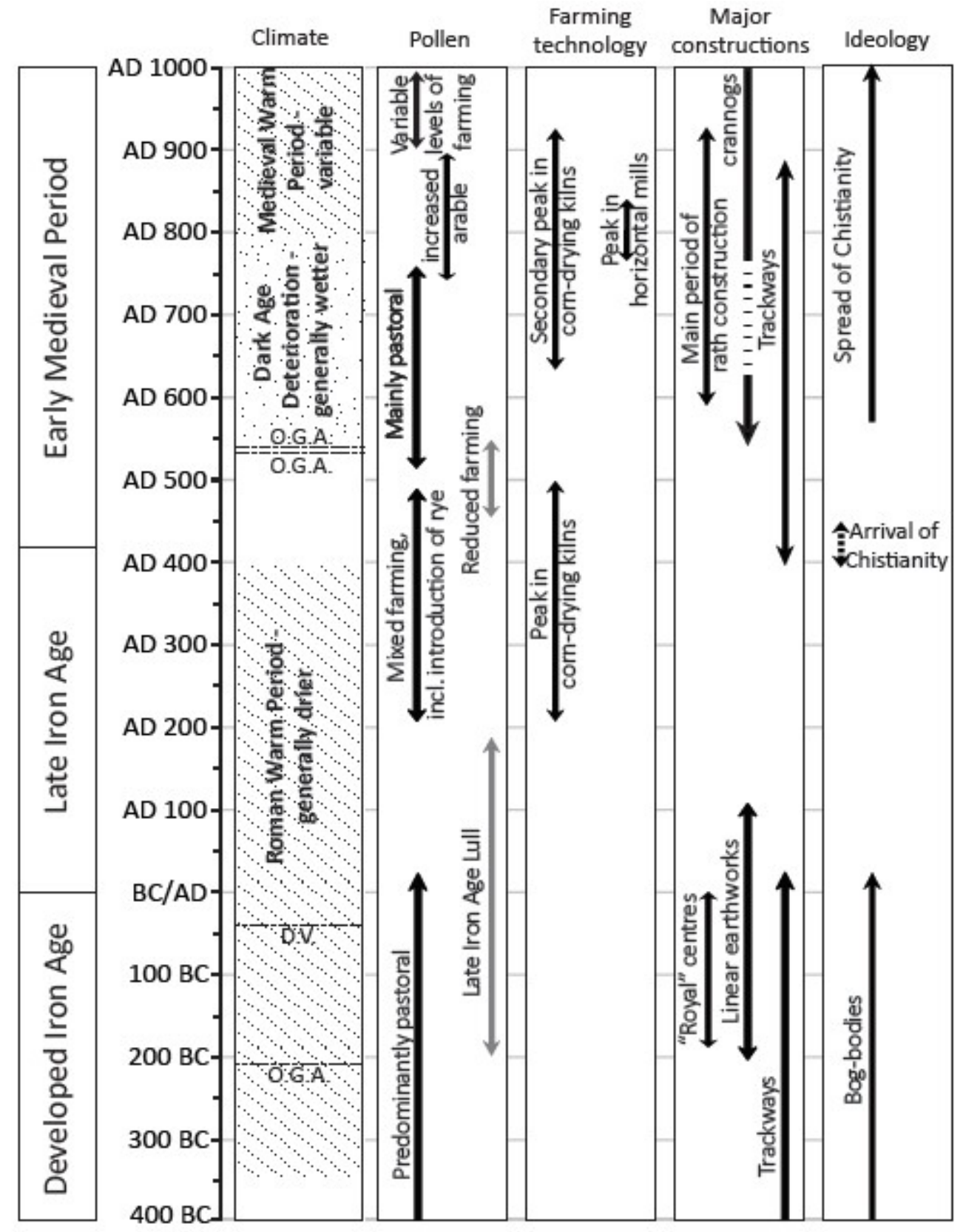

FIG. 7-Summary of the main palaeoclimate, pollen and cultural changes in Developed to Late Iron Age and early medieval period. DV - dust veil event; OGA - oak growth anomaly. 